\title{
44. MESOZOIC-CENOZOIC GEOLOGY OF THE EASTERN MARGIN OF THE GRAND BANKS AND ITS RELATION TO GALICIA BANK'
}

\author{
A. C. Grant, L. F. Jansa, K. D. McAlpine, and A. Edwards, Geological Survey of Canada, Atlantic Geoscience \\ Centre, Bedford Institute of Oceanography, Dartmouth, Nova Scotia, Canada
}

\begin{abstract}
Late Paleozoic reconstructions of the North Atlantic juxtapose the eastern margin of the Grand Banks with the continental margin off Iberia. Comparison of the geology of the Grand Banks region with results from ODP Leg 103 on the Galicia margin improves our understanding of the Mesozoic-Cenozoic tectonic evolution of these regions and provides new constraints on pre-drift fits.

The Grand Banks region is underlain by Paleozoic and Precambrian rocks of the Appalachian Orogen, which were rifted, eroded, and buried during Mesozoic and Cenozoic tectonic episodes related to formation of the North Atlantic Ocean and the Labrador Sea. The Carson Basin along the eastern margin of the Grand Banks contains Triassic and Jurassic evaporites overlain by Jurassic and Cretaceous carbonate and clastic rocks that were deeply eroded during the mid-Cretaceous. This unconformity is overlain by a comparatively thin and undeformed sequence of Cretaceous-Tertiary fine-grained marine clastics. Since the mid-Cretaceous, the outer portion of the Carson Basin has subsided to oceanic depths and now underlies the slope-rise zone. Comparison of the seismic stratigraphy of the Carson Basin with that of the Galicia margin indicates similar tectonic histories and depositional environments from Triassic to Tertiary time. Seismic-reflection data have been used to map the minimum seaward extent of continental crust, and this boundary lies approximately along a "headland to headland" line between the Newfoundland Ridge and Flemish Cap. Regional juxtaposition of these margin segments is geologically reasonable, but the evidence for continental crust beneath the slope and rise southeast of the Grand Banks precludes fitting Galicia Bank in this zone.
\end{abstract}

\section{INTRODUCTION}

Masson and Miles (1984) and Srivastava and Tapscott (1986), among others, have discussed the problems in paleogeographic reconstructions of Iberia relative to Europe and North America (Fig. 1). Such reconstructions generally place the Iberian Peninsula opposite the southeastern Grand Banks, with Galicia Bank (where Ocean Drilling Program (ODP) Leg 103 drilled), Flemish Cap, and Newfoundland Ridge presenting obstacles to tight juxtaposition of the two margins (Fig. 2). In this paper we review the geology of the Grand Banks region, with emphasis on comparing the Mesozoic-Cenozoic evolution of its eastern margin with that of the Galicia Bank area. We examine the nature of the crust in the slope-rise zone between Newfoundland Ridge and Flemish Cap and compare the seismic stratigraphy of this zone with that of Galicia Bank. These observations provide constraints on fitting the Grand Banks and Iberia and may be useful for future comparative studies.

The interpretations in this paper are based mainly on analysis of geophysical and geological data derived from petroleum exploration. Additional geophysical and geological data have been utilized from a variety of government and academic institution surveys in the region.

\section{REGIONAL GEOLOGY}

The structure and stratigraphy of the Grand Banks region have been discussed by Amoco and Imperial (1973), Jansa and Wade (1975), Hubbard et al. (1985), Grant et al. (1986), Grant (1987), Enachescu (1987), Grant and McAlpine (in press), Keen et al. (1987), and Tankard and Welsink (in press).

The broad continental shelf around Newfoundland is a prominent physiographic feature at the junction of the northeast-

\footnotetext{
${ }^{1}$ Boillot, G., Winterer, E. L., et al., 1988. Proc. ODP, Sci. Results, 103: College Station, TX (Ocean Drilling Program).
}

trending Atlantic margin and the northwest-trending Labrador Sea margin of North America (Fig. 1). The continental shelf is underlain by the northeastern continuation of the Appalachian Orogen of eastern North America, which is the product of the Taconian (Middle Ordovician), Acadian (Devonian), and Alleghenian (Permo-Carboniferous) orogenies (Williams, 1979). Offshore the Paleozoic and Precambrian rocks of the Appalachian Orogen are buried by Mesozoic and Cenozoic sedimentary deposits. The primary geologic elements of the Newfoundland margin are thus the Precambrian-Paleozoic rocks, which are treated as "basement" in this paper, and the overlying Mesozoic-Cenozoic sedimentary cover. In general, the Mesozoic sediments occupy structural basins, and the Cenozoic sediments form a regional blanket on the continental margin.

The most prominent subsurface geologic features of the Grand Banks region shown by industry seismic data are a peneplain (the Avalon Unconformity) beneath undisturbed Upper Cretaceous and Tertiary strata and a series of structured Mesozoic basins beneath this peneplain (Figs. 3 and 4). The basins began to develop during Late Triassic rifting between North AmericaGreenland and Europe-Africa. The northeast orientation of the basins beneath the Grand Banks is approximately parallel to the structure of the Appalachian Orogen exposed onshore in Newfoundland. However, north of the Grand Banks the trend of the sedimentary basins swings through north to northwest (Fig. 4) and cuts across the projected grain of the Appalachians. These structural trends are approximately parallel to the present physiographic margin and may relate to the formation of the similarly aligned Labrador Sea.

Africa began to separate from North America in the Early Jurassic, with inferred development of a transform fault along the southwestern margin of the Grand Banks (McWhae, 1981). The Grand Banks experienced only epeirogenic subsidence until the Late Jurassic.

Doming of the Grand Banks region (the Avalon Uplift) in the latest Jurassic is associated with a second period of rifting that culminated in the separation of Iberia from the Grand 


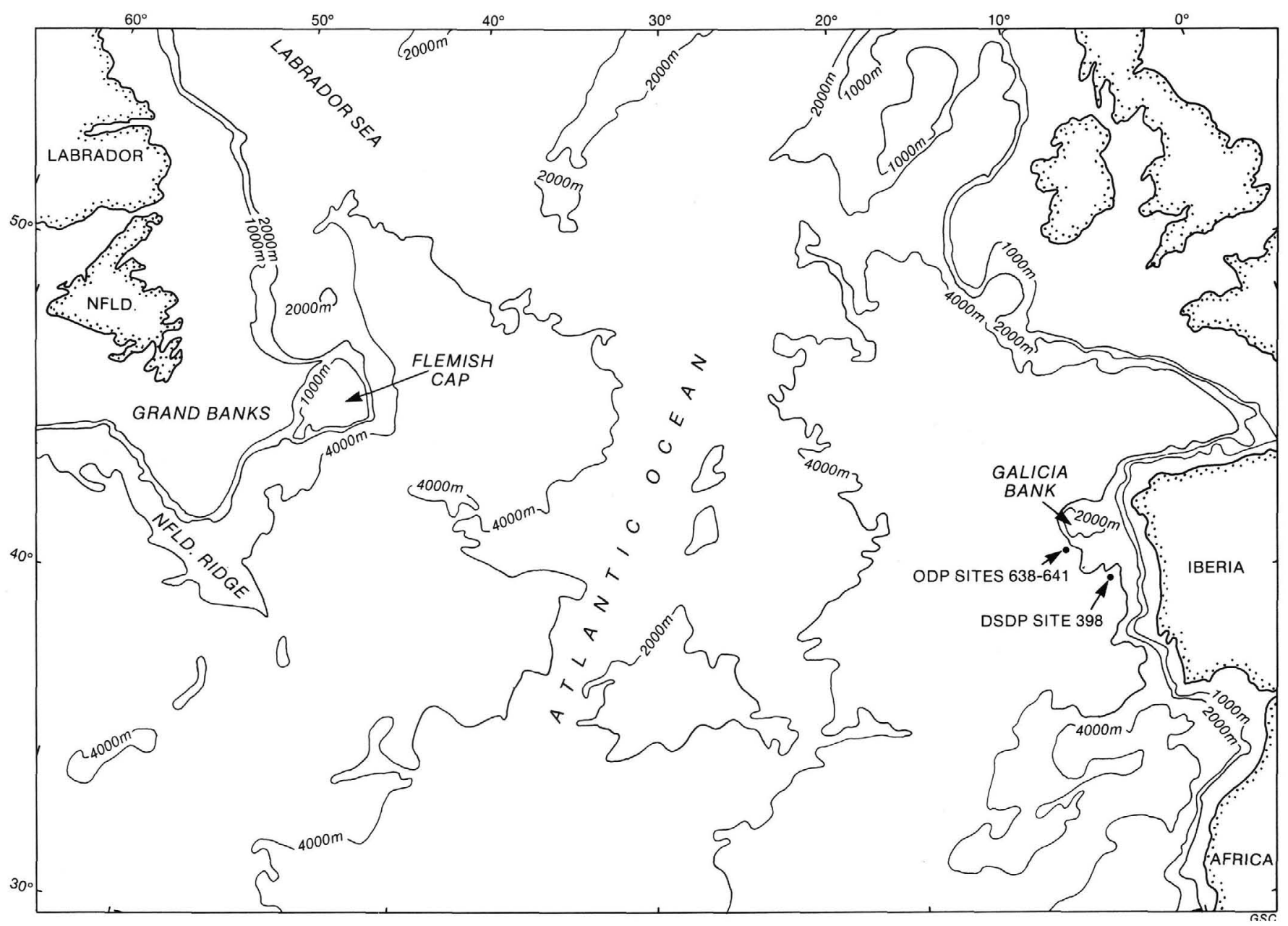

Figure 1. Generalized bathymetry map of the North Atlantic. Numbered dots are selected DSDP and ODP drilling sites, including Leg 103 locations.

Banks in the late Early Cretaceous (Jansa and Wade, 1975). The formation at this time of the southeastern margin of the Grand Banks was a major stage in the development of the prominent peneplain on the Grand Banks, the Avalon Unconformity.

The Avalon Uplift forms a regional arch that trends southeast from the Avalon Peninsula to the Newfoundland Ridge (Fig. 3). Erosion associated with the Avalon Uplift cut deeply into deformed Jurassic rocks in the central basins on the Grand Banks; progressively younger strata are present beneath the Avalon Unconformity in the basins flanking the Avalon Uplift. These flanking basins contain several erosional surfaces that coalesce updip to merge with the interbasin peneplain, and collectively, they indicate that this surface expresses at least 50-60 m.y. (late Kimmeridgian to Albian-Cenomanian) of deformation, uplift, and erosion. Locally this surface shows the effects of Tertiary erosional events associated with eustatic sea-level changes.

The geology of the Grand Banks region at this described level of the peneplain is indicated in Figure 5. The basins beneath the peneplain preserve remnants of a northeast-trending Jurassic seaway that extended across the Grand Banks and turned northward to the east of Newfoundland. Jansa and Wade (1975) and Swift and Williams (1980) sketched the original boundaries of this seaway, showing the South Bank High and Flemish Cap as positive areas to the southeast and east. Figure 5 shows Jurassic rocks south of the South Bank High, indicating that it might have been an insular feature in the Jurassic, with the Jurassic seaway extending south of the Grand Banks through the Fogo Basin to the Carson Basin. P. Ascoli (pers. comm., 1986) has described the Late Jurassic fauna in the Bonnition H-32 well in the Carson Basin as having more "open Atlantic" affinities than the coeval fauna in the Jeanne d'Arc Basin.

\section{Jeanne d'Arc Basin}

The deepest of the Mesozoic basins on the Grand Banks is the Jeanne d'Arc Basin (Figs. 6 and 7); depth contours in Figure 6 are conservative because basement lies below the recording depth of conventional, industry seismic records. A deep seismic-reflection line across the Jeanne d'Arc Basin shows that it is more than $20 \mathrm{~km}$ deep (Keen et al., 1987). Because the best understood and most complete Mesozoic record of the Grand Banks is preserved in this basin, its structure and stratigraphy are reviewed briefly in the following. These results are then extrapolated-mainly with geophysical data-to the eastern margin of the Grand Banks, where comparatively few wells have been drilled.

\section{Structure}

The Bonavista Platform, flanking the Jeanne d'Arc Basin to the west (Fig. 6), is composed of probable pre-Mesozoic rocks. The "Outer Ridge Complex" that forms the east flank of the basin is an area of northeast- to north-trending ridges of basement and deformed sedimentary strata. The latter are in part age-equivalent to Jurassic and Cretaceous strata in the basin, 

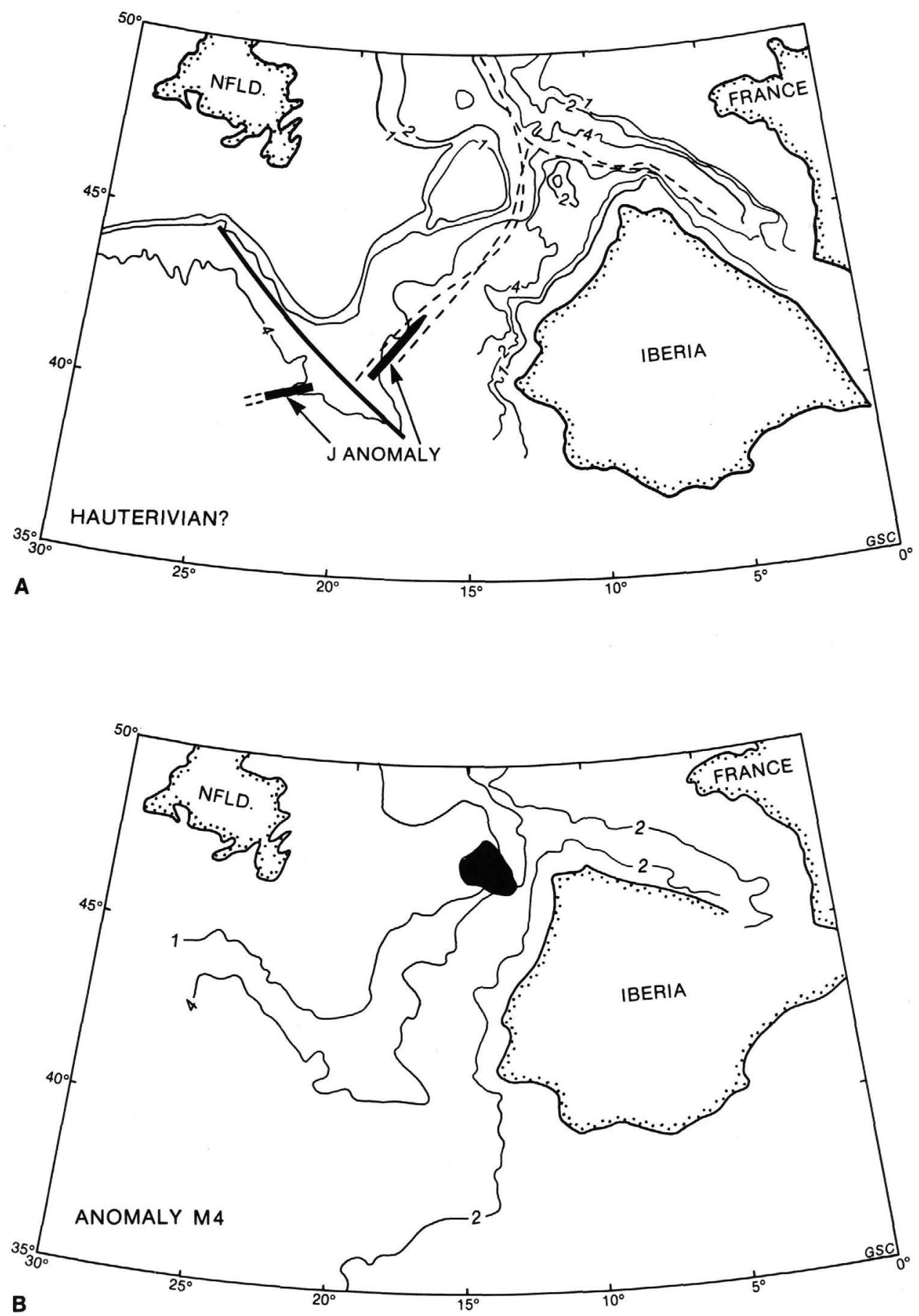

Figure 2. "Pre-drift" reconstructions of the North Atlantic (A) after Masson and Miles (1984; figure 3a. Initial opening) and (B) after Srivastava and Tapscott (1986; figure 6. Anomaly 4 time). Depth contours in kilometers. Black area in Figure 2B denotes overlap of Galicia Bank and Flemish Cap.

but may include Paleozoic rocks. The basement ridges may consist of Paleozoic metasedimentary or granitic rocks or of Precambrian rocks, as occur on Flemish Cap (Pelletier, 1971; King et al., 1985). Grant et al. (1986) proposed that the principal controls on the structure of the Jeanne d'Arc Basin were periods of relative subsidence and uplift and superimposed effects of salt or shale flowage. Structures resulting from flowage include diapirs and pillows and listric faults with associated rollover anticlines (Fig. 7). The sedimentary fill of the basin can be viewed as "floating" on a substrate of salt or incompetent, overpressured shale; structural disruption of the marginal areas of the basin is largely the product of compensatory movement for salt or shale flowage in the axial part of the basin (Grant, 1987). These movements may have been triggered by displacements on underlying basement faults.

Three main sets of faults disrupt the sediments in the Jeanne d'Arc Basin: listric-type faults approximately parallel to the margins of the basin, high-angle normal faults approximately parallel to the margins of the basin, and trans-basin faults orthogonal to the other two sets. The principal trans-basin faults 


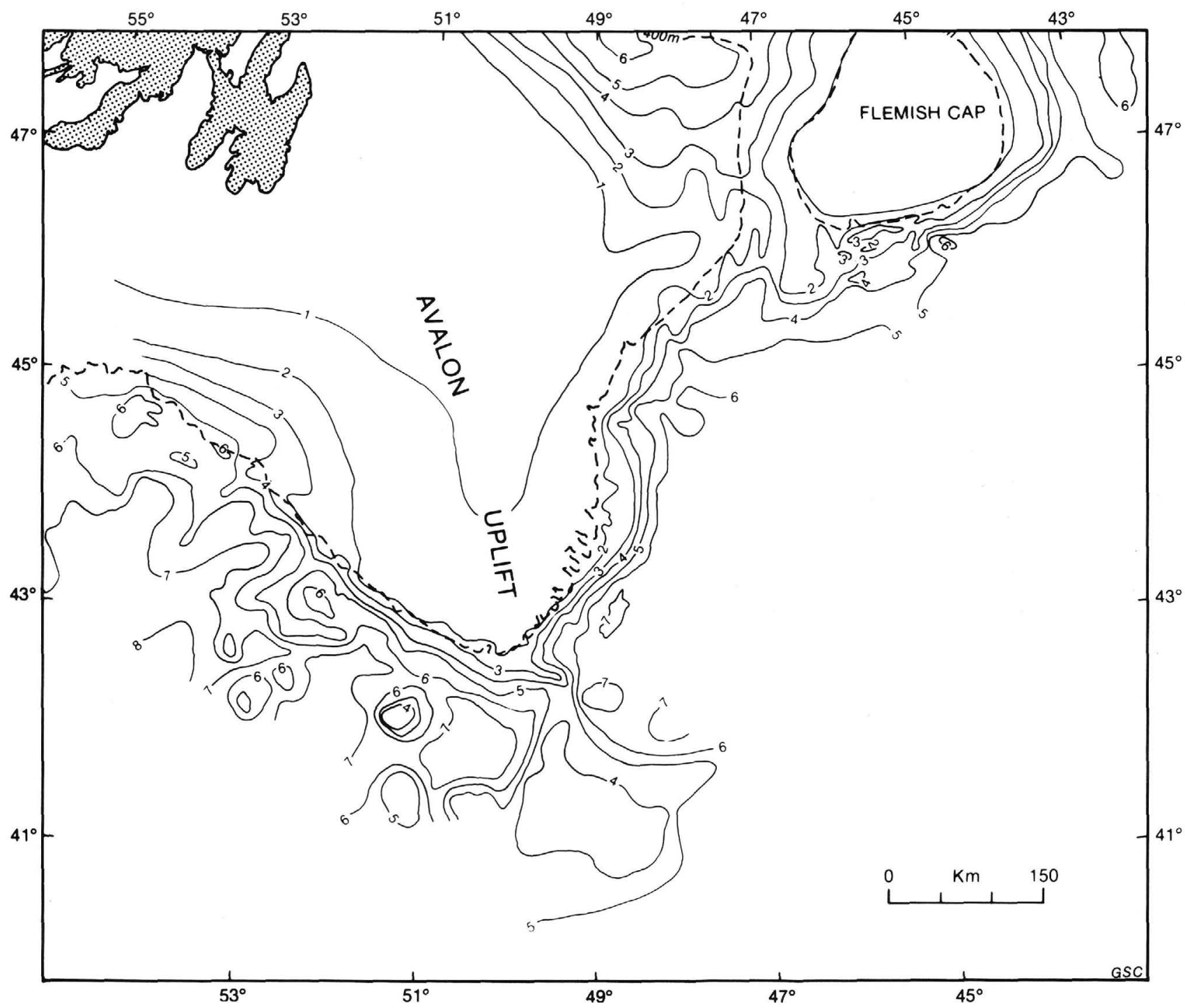

Figure 3. Structure contour map (in kilometers) of "base event," which comprises the deepest seismic horizons that can be mapped regionally (after Grant and McAlpine, in press). Beneath the Grand Banks this surface corresponds approximately to the Avalon Unconformity or base of the Upper Cretaceous; beneath the adjacent slope-rise zone it approximates the Cretaceous/Tertiary boundary. Dashed lines trace the present-day shelf edge $(400-\mathrm{m})$ depth contour.

appear to be over zones of normal faulting in the basement. The basin can be divided into three structural segments that are separated by two zones of trans-basin faults (Fig. 6). A strong, sloping seismic reflector that can be mapped along much of the west side of the Jeanne d'Arc Basin has been referred to as the basement "hinge" zone (Grant, 1975). This reflector, which becomes nearly horizontal at depth, is related to a surface on which the overlying sediments show some eastward displacement toward the axial zone of the basin.

\section{Stratigraphy}

The stratigraphic evolution of the Jeanne d'Arc Basin is intimately related to its structural history and may be satisfactorily described in a plate tectonic framework. In brief, the Mesozoic stratigraphy developed as a complex response to protracted rifting and continental breakup between the Late Triassic and the end of the Cretaceous. The Cenozoic stratigraphy, in contrast, is a relatively simple response to passive margin subsidence. The preserved sediments record two periods of rifting and an intervening period of tectonic stability. The last rift phase was fol- lowed by a two-stage transition to the tectonic setting of a passive continental margin.

The stratigraphic record can be divided into six depositional sequences based on widely mappable seismic sequences that have been synthesized with lithostratigraphic and biostratigraphic data from oil exploration wells (Fig. 8). The strata within each sequence are the product of a unique tectonic episode in the construction of the continental margin of eastern Canada. These sequences are approximately correlative to the four Grand Banks megasequences proposed by Hubbard et al. (1985); they are also consistent with the scenario for the development of sedimentary basins around the North Atlantic discussed by Masson and Miles (1986). However, our interpretation of the time of initiation of the second period of rift subsidence (Kimmeridgian) differs from that of Tankard and Welsink (in press), who began this rift phase in the Callovian. Their account is based on an interpreted "major late Callovian unconformity" and the simpleshear model of Wernicke (1985) to explain basin development by crustal extension. We see little evidence to document a late $\mathrm{Cal}$ lovian tectonic event, and we cannot endorse Wernicke's model 


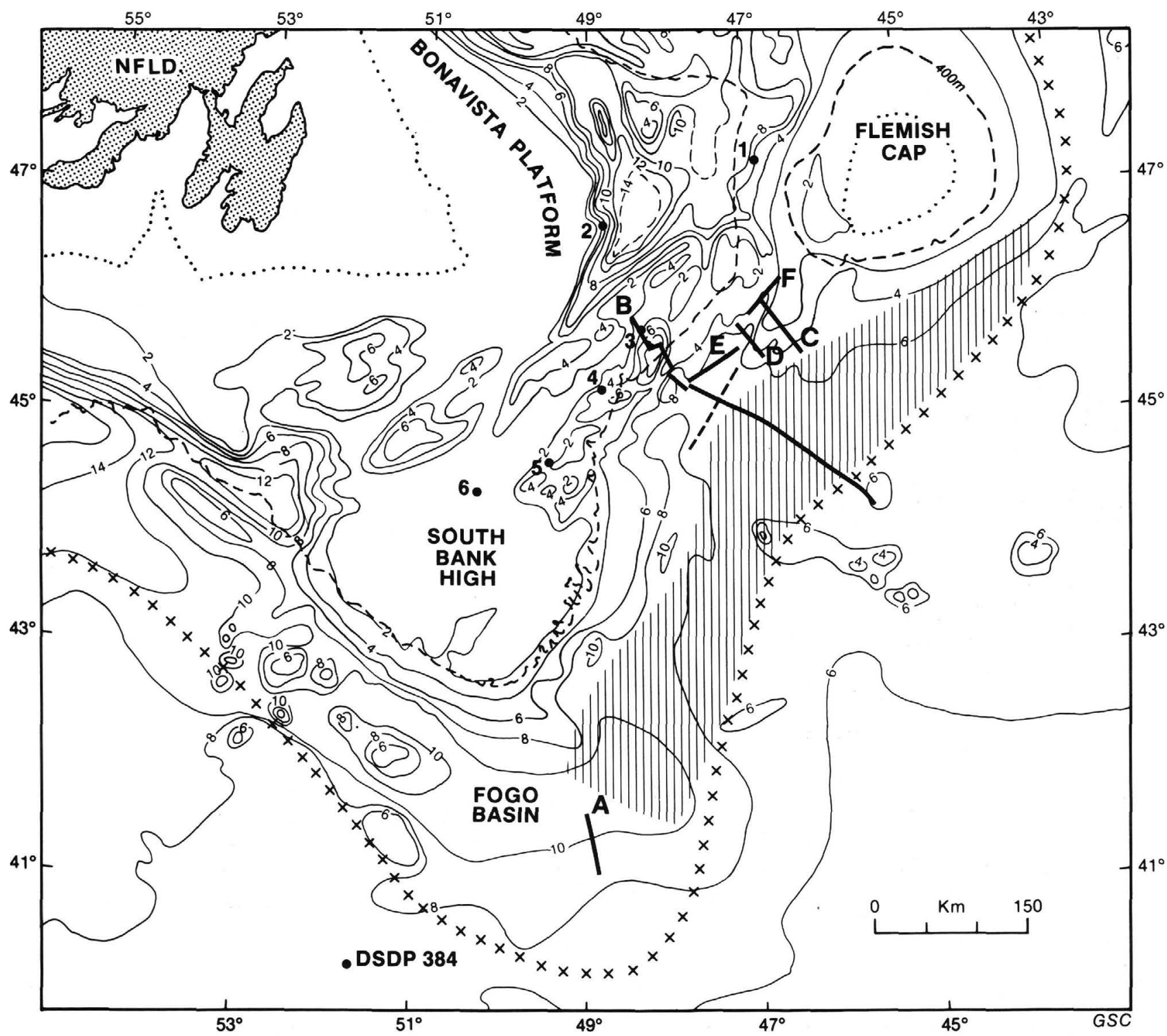

Figure 4. Structure contour map (in kilometers) of seismic "basement." Dotted line is edge of the Cretaceous/Tertiary boundary. Shaded area is zone of "intermediate" crust defined by Parson et al. (1985). Numbered dots are selected well locations: $1=$ Gabriel, $2=$ Hibernia, $3=$ Bonnition, 4 = Skua, 5 = Osprey, 6 = Jaeger. Lettered lines mark locations of seismic lines and cross sections in Figures 9 through 13 . X's trace continent/ocean boundary interpreted from seismic-reflection data. Heavy dashed line is southwest projection of Beothuk Ridge.

to explain the formation of the Grand Banks basins. We prefer to interpret depositional sequence bases on style of sedimentation, which infers that the Kimmeridgian unconformity and accompanying accumulation of coarse clastics signal the onset of the second rifting phase.

\section{Sequence 1- “Aborted Rift," Late Triassic to Early Jurassic}

Sequence 1 overlies pre-Mesozoic basement. It consists of red beds, evaporites, and carbonates deposited in an extensive rift system that developed between North America-Greenland and Europe-Africa and extended into the area of the present North Sea.

The Kettle, Eurydice, Osprey, Argo, and Iroquois formations make up this sequence (Fig. 8). Their dominant lithologies are coarse-grained red clastics (Kettle red beds), reddish shale-siltstone (Eurydice Formation), halite (Osprey and Argo formations), and anhydritic dolomite and oolitic and skeletal limestones (Iroquois Formation). These rocks record gradual progression from a continental depositional environment accompanying initial rifting to deposition in marine water from the Tethys as rifting progressed. Deposition occurred in an arid climatic belt in restricted evaporite basins, followed by coastal sabkhas, tidal flats, and restricted lagoons, and finally, by a shallow sea.

A thin unit of subaerial basalt flows between the Argo and Osprey salts has been encountered in two wells (Spoonbill and Cormorant; Fig. 6). These basalts can be followed as a prominent seismic event over much of the southern Jeanne d'Arc Basin. From their stratigraphic position, the basalts are latest Triassic to earliest Jurassic in age and are broadly synchronous with a widespread igneous event associated with the first stage of North Atlantic rifting (Hodych and Hayatsu, 1980; Jansa and Pe-Piper, 1986). In the Carson Basin (Figs. 4 and 5) the Osprey well encountered a 2054-m-thick halite sequence of Carnian to Sinemurian age (Jansa et al., 1977). A prominent seismic event displaying some discordant relationships occurs between the Osprey and Argo salts (Holser et al., in press), and 


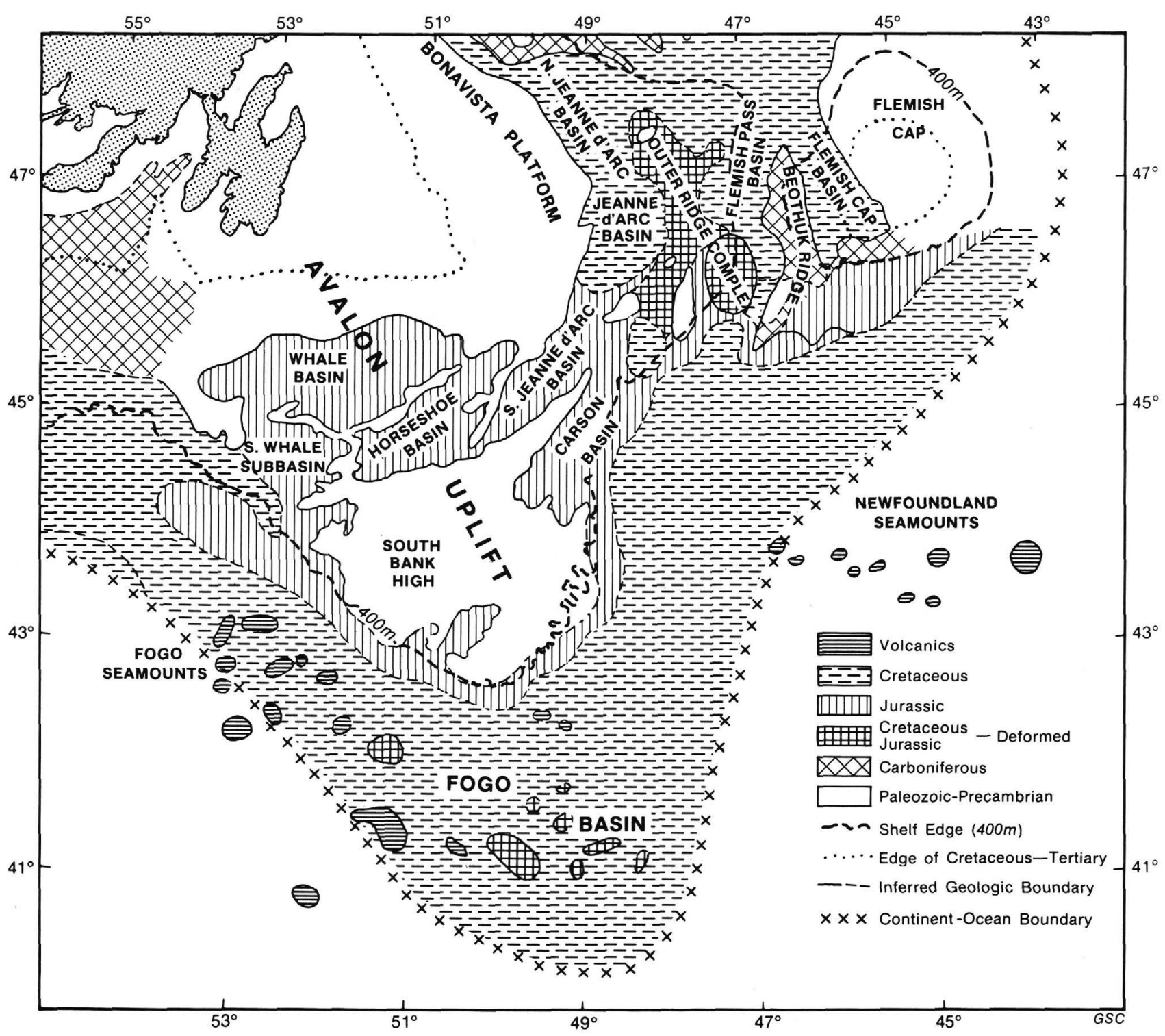

Figure 5. Generalized geology map drawn at the level of the peneplain (Fig. 3) beneath the Grand Banks. After Grant and McAlpine (in press).

palynological dating (Jansa et al., 1980a) indicates that this event may be related to the igneous extrusion recorded by the basalts in the Jeanne d'Arc Basin. The salt extends beneath the continental slope-rise zone to the southeast, as discussed subsequently.

\section{Sequence 2- "Epeiric Basin," Early to Late Jurassic}

Rifting ceased during the late Early Jurassic northeast of the southwestern edge of the Grand Banks. During the Early Jurassic, marine carbonates and continental clastics dominated deposition on the Scotian Shelf and northwest African margin (Jansa and Wiedman, 1982). However, the shallow-marine carbonates (Iroquois Formation) deposited on the Grand Banks in Sinemurian time were succeeded by mainly marine neritic shales during late Pliensbachian time.

The Whale unit (Fig. 8) consists of a lower shale, a middle limestone, and an upper shale. The relative development of these facies varies regionally, and lithostratigraphic boundaries are probably diachronous within the unit. The lower shale is gray, calcareous, and marly, and becomes less calcareous and medium dark gray toward the top. Skeletal-pelletoidal wackestones and packstones with rare oolite-rich beds dominate the middle limestone facies. The limestones were deposited in a high-energy, shallow epicontinental sea during a regressive period in the Aalenian-Bajocian. Progressive deepening of the marine environment during the Bathonian led to deposition of the upper shale, which is gray, calcareous, and contains occasional beds of siltstone and fine-grained sandstone. The ostracode and foraminifer assemblages indicate that the upper shale unit was deposited in middle neritic environments (P. Ascoli, pers. comm., 1985; Stam, 1986).

A variety of lithofacies make up the Upper Jurassic (Oxfordian-Kimmeridgian) Mic Mac Formation. In the lower part, shales are intercalated with fine- to medium-grained quartzose sandstone, with subordinate oolitic limestone and reddish brown shale and coal, which indicates a shallow to marginal marine depositional environment. The upper Mic Mac consists of 


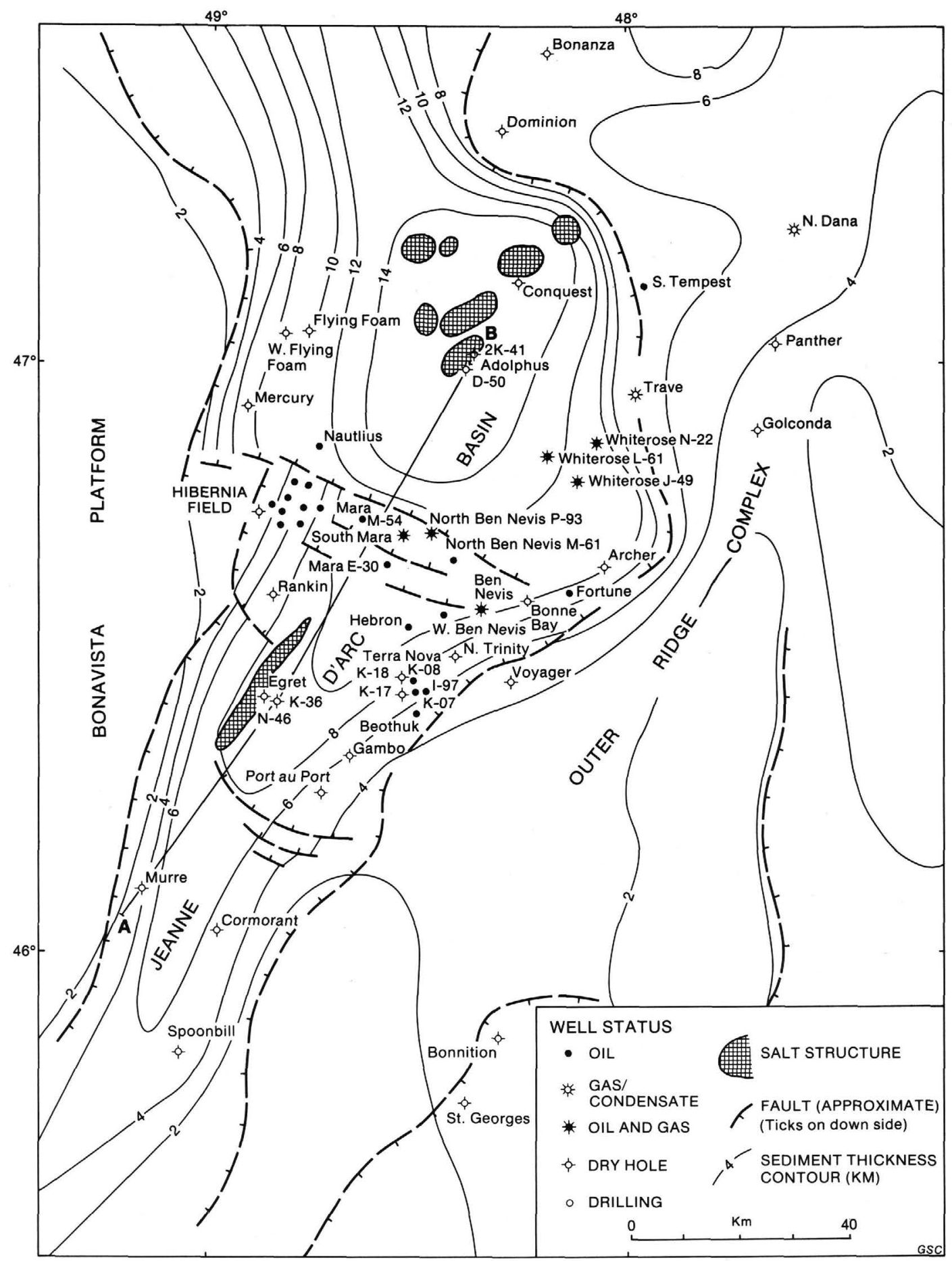

Figure 6. Diagrammatic structure and sediment thickness map of the Jeanne d'Arc Basin. After Grant et al. (1986). Line A-B shows location of cross section in Figure 7.

shales and shallow-water skeletal, peloid, and oolitic limestones intercalated with subordinate, very fine- to fine-grained quartz sandstones. Sandstones and shales become the dominant lithofacies in the north.

A distinctive, 75-150-m-thick shale unit of middle Kimmeridgian age is present near the top of the Mic Mac Formation in the Jeanne d'Arc Basin. The shale is gray to brown, carbonaceous, and calcareous. Interbeds of marl are common in some areas. Organic carbon content is very high, between $3 \%$ and $9 \%$. Lack of foraminiferal microfauna and the occurrence of ostracodes in the shale indicate deposition in a restricted marine environment or brackish lagoons (P. Ascoli, pers. comm., 1986). The shale unit thickens to the northeast, where more open marine conditions prevailed and the organic facies became diluted by clays. Oil-oil and oil-source correlation studies show that this shale is the principal source rock for all the oils discovered in the Jeanne d'Arc Basin (Powell, 1984; McAlpine et al., 1986; Grant and McAlpine, in press). 


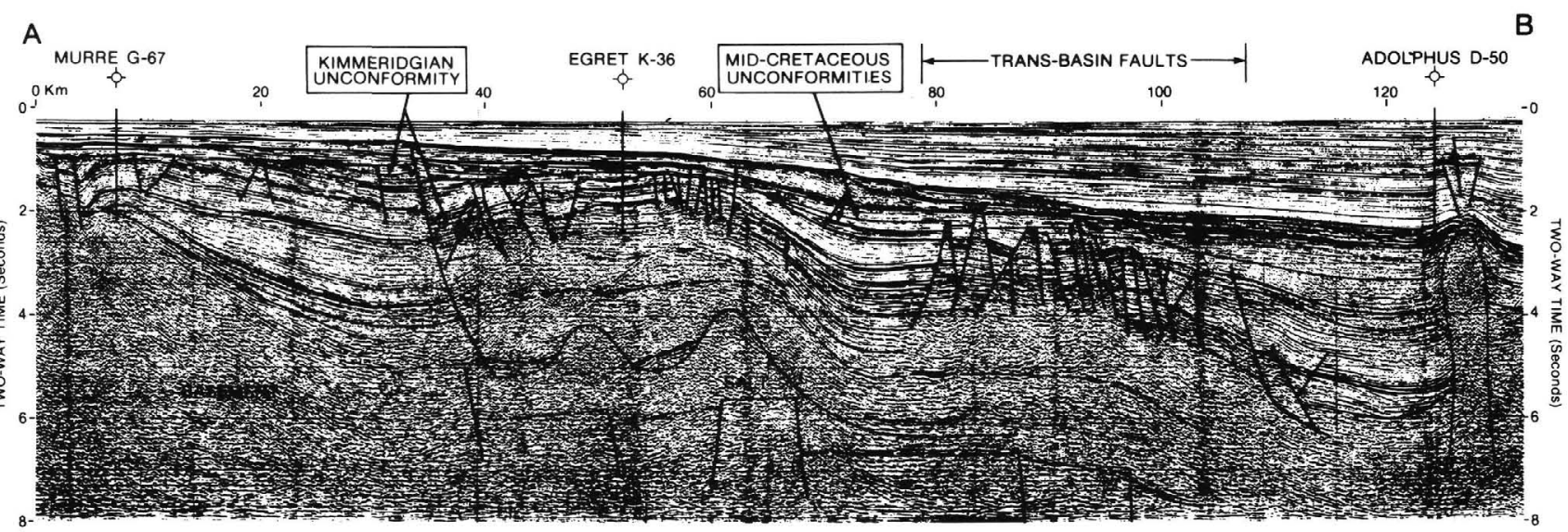

(a)

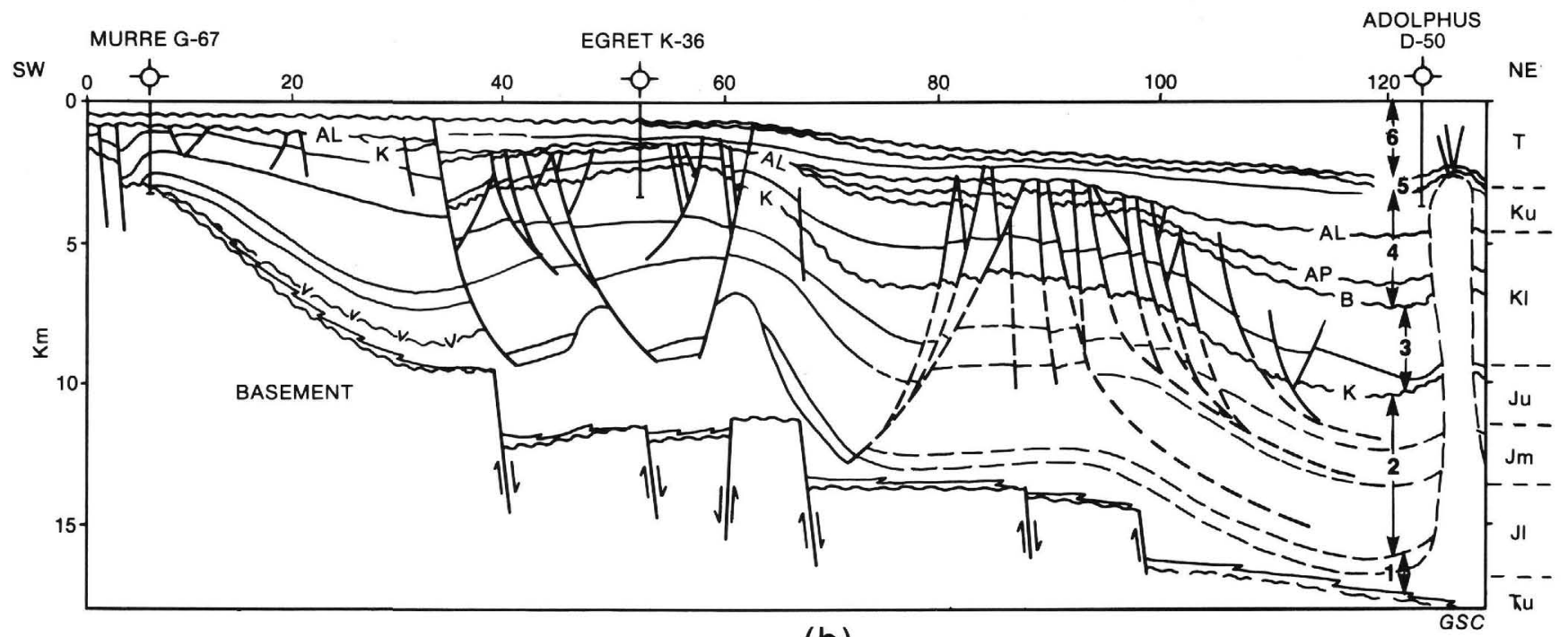

(b)

Figure 7. A. South to north seismic line approximately along the axis of the Jeanne d'Arc Basin. Line of section shown in Figure 6. Notable features discussed in the text include the Kimmeridgian unconformity, which exhibits prominent channeling in the vicinity of the Egret K-36 well; three mid-Cretaceous unconformities that bound two onlapping-fill seismic sequences; and the large fault about $15 \mathrm{~km}$ south of the Egret K-36 well that offsets the Kimmeridgian unconformity by about 1.2 s and overlies an important basement fault (after Grant and McAlpine, in press). Part of seismic line NF 79-112 (courtesy of Geophysical Service Incorporated). B. Geologic interpretation of seismic profile in Figure 7A. See Figure 8 for explanation of depositional sequences 1-6 and the unconformities K, B, AP, and AL. After Grant and McAlpine (in press).

The top of sequence 2 is a middle Kimmeridgian unconformity, which delineates a new period of taphrogenesis in the geologic development of the Grand Banks.

\section{Sequence 3- "Late Rift," Latest Jurassic and Neocomian}

Continental and shallow-marine clastics were deposited above the unconformity in the basins developing on the flanks of the Avalon Uplift (Carson and Jeanne d'Arc basins and South Whale Sub-basin; Fig. 5). However, regional uplift outpaced basin subsidence on the axis of the Avalon Uplift, which was deeply eroded. Hubbard et al. (1985) suggested that Early Cretaceous subsidence in the Jeanne d'Arc Basin was influenced by a northwest-trending rift system that they named the Labrador Rift system. The northwest-trending trans-basin fault south of the Egret well has a throw of about $2 \mathrm{~km}$ and overlies a major basement fault (Figs. 6 and 7). Movement on both faults began in the earliest Cretaceous (Berriasian), which may coincide with the initiation of rifting and volcanic activity on the Labrador Shelf (McWhae, 1981). Depositional thickening toward the major northwest-trending boundary fault in the northern part of the Jeanne d'Arc Basin suggests that tectonism extended into the late Early Cretaceous. The timing and the orientation of these faults parallel to the Mesozoic basins of the Labrador Shelf suggest that overprinting by the Labrador Sea tensional regime enhanced subsidence in the Jeanne d'Arc Basin and complicated the Cretaceous stratigraphy of the Grand Banks.

Average sedimentation rates in the Jeanne d'Arc Basin of 11 or $12 \mathrm{~cm} / 1000$ yr during the Middle to early Late Jurassic (sequence 2) almost doubled to $20 \mathrm{~cm} / 1000 \mathrm{yr}$ during the late Kimmeridgian. Basin subsidence was rapid at first but decreased quickly. The basin was filled by fluvial fan and fan-delta deposits of the Jeanne d'Arc member, coastal plain-delta top and delta front-prodelta sediments of the Hibernia member, interdistributary bay and shallow marine shoreface facies of the " $C$ " member, and estuarine to tidal flat sandstones and siltstones of the lower Avalon member (Fig. 8). The sediments fine upward overall, which we interpret as reflecting gradual peneplanation of the source areas and filling of the basin. The sandstone units are isolated vertically from one another by shales deposited when the source areas were relatively low or during periods of positive eustacy and associated marine transgression. 


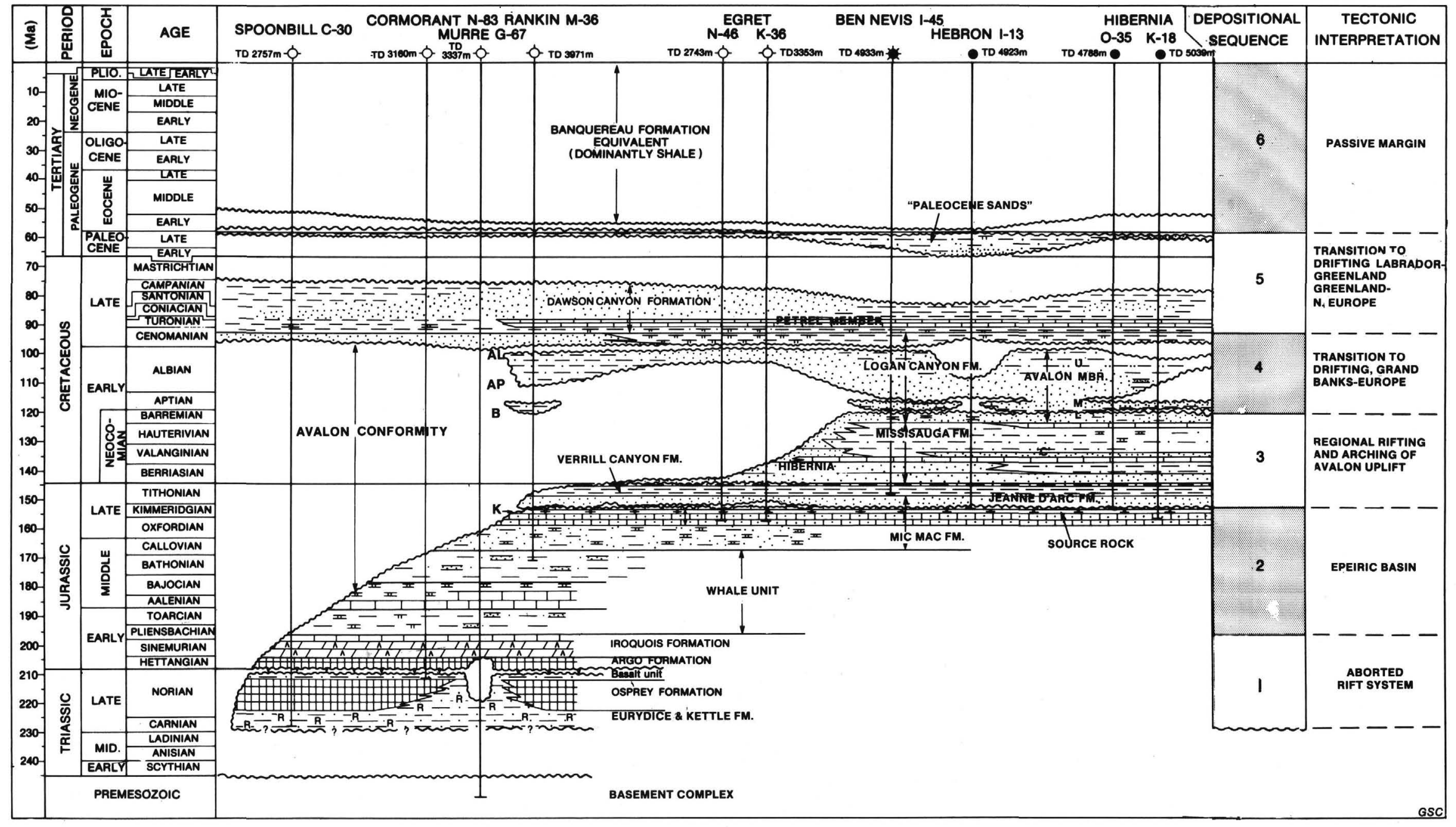

SANostone E:

\section{: volvanics}

Figure 8. Time-stratigraphic section of the Jeanne d'Arc Basin showing lithostratigraphic framework and major depositional sequences. Well locations are in Figure 6. The Avalon Unconformity, a prominent peneplain buried beneath the central Grand Banks, records the net effect of at least four erosional events that are identified by well and seismic data in the Jeanne d'Arc Basin. The times of these events are Kimmeridgian (K), late Barremian (B), late Aptian (AP), and late Albian-Cenomanian (AL) (after Grant and McAlpine, in press). 


\section{Sequence 4- "Transition to Drift: Phase I," Barremian to Cenomanian}

The siliciclastic units of sequence 4 (Logan Canyon Formation; Fig. 8) were deposited during the inferred time of continental separation between the Grand Banks and Iberia. Rifting continued in the Labrador Sea and incipient continental spreading occurred between the Grand Banks and north Europe at this time (Deep Sea Drilling Project (DSDP) Site 550; de Graciansky, Poag, et al., 1985).

Subsidence began to slowly increase in the latest Barremian and Aptian, but the hinterland was still low-lying, and the initial sediments of the middle Avalon member consist of finegrained estuarine sandstones and lagoonal and tidal flat shales. The base of this sequence is an easily recognizable seismic event; although often erosional at the basin margins and over local structures, it generally represents a surface of seismic onlap (Fig. 7). In several wells (e.g., Hibernia B-27, South Mara C-13, and Ben Nevis I-45), a red mudstone unit occurs just above the Barremian unconformity. This red mudstone is locally emergent, contains rootlets, and records a period of very slow, possibly intermittent, deposition.

A new period of basin structuring is recorded by the transbasin faults trending southwest from the Hibernia field (Fig. 6) and by the sediments of the upper Avalon member. Fault movement was mainly during the Albian (Fig. 7), between the middle and upper unconformities within sequence 4 . These unconformities are late Aptian and late Albian in age.

The upper Avalon member is a syntectonic deposit consisting of shallow estuarine channel and tidal flat sands. Sediment was supplied from the margins down the axis of the basin and locally from high-standing fault blocks. These sands record the last period of faulting that affected the Jeanne d'Arc Basin, and we interpret them as the record of continental breakup between the Grand Banks and southern Europe.

The late Albian tectonic event at the top of the upper Avalon member was less erosive than the late Aptian unconformity. Angularity is observed only at the basin margins and over the most prominent basin structures. In a sense, it represents a base-level surface resulting from syntectonic infill and beveling of the $\mathrm{Al}$ bian structures. In the basin depocenter, where marls and shallow-water shales and siltstones were deposited, the prominent seismic onlap observed over this surface indicates that the basin was subsiding faster than sediment input. In the tectonically stable southern part of the basin, the Eider unit overlying the upper Albian unconformity consists of brown and reddish, medium- to coarse-grained sandstones and conglomerates deposited in a continental to marginal marine environment.

Sequence 5- "Transition to Drift: Phase II," Late Cretaceous and Paleocene

Complete separation of the Grand Banks from northern Europe probably occurred during this period (Masson and Miles, 1984). Sediment supply was intermittent and produced overlapping deltaic sequences with distal turbidites. Deep-water chalky limestones were deposited when subsidence outpaced sediment supply. Unconformities of Late Cretaceous and early Tertiary age are inferred to relate to the breakup between Labrador and Greenland and Greenland and northern Europe.

Transgressive marine sediments of Cenomanian and Turonian age in the lower part of the Dawson Canyon Formation consist mainly of shales with minor siltstone and sandstone deposited in a neritic environment (Fig. 8). The chalky Petrel Member was deposited in an outer neritic environment at the end of this period. Within the Senonian (Coniacian-Maestrichtian), prograding clinoforms observed on seismic lines in the Jeanne d'Arc Basin indicate an influx of clastics from the west that formed an offlapping clastic wedge (Fig. 7). Equivalent deeper water sediments are the Wyandot Formation chalks. Both the Turonian and Coniacian-Maestrichtian chalk deposits reflect periods of eustatic sea-level rise. A major unconformity with prominent channeling into the underlying Dawson Canyon Formation (Fig. 8) is of latest Cretaceous-Paleocene age. Delta front sands and prodelta turbidites of Paleocene age ("Paleocene sands"; Fig. 8) overly the unconformity.

\section{Sequence 6- "Passive Margin," Tertiary}

By Eocene time the Grand Banks were surrounded by oceanic crust. Seaward tilting of the passive margin led to deposition of widespread deep neritic shales with minor chalks, siliceous mudstones, and rare sand-silt beds of the Banquereau Formation (Jansa and Wade, 1975). This was a time of global change in eustatic sea level and in patterns of circulation, upwelling, and climate; the modern shelf, slope, and rise were established (Fig. 1). Paleoenvironmental data from the Tertiary sections in East Newfoundland Basin wells indicate a change in Oligocene time from deep neritic and bathyal depositional conditions to shallow neritic environments (Gradstein and Williams, 1981). Sea level lowered again in the middle to late Miocene, and much of the Grand Banks may have been exposed subaerially. At the present time, the erosional and depositional record of this regression cannot be distinguished unequivocally from the effects of Pleistocene lowerings of sea level.

\section{EASTERN MARGIN OF THE GRAND BANKS}

The Carson Basin, along the eastern edge of the Grand Banks (Figs. 4 and 5), experienced the structural and stratigraphic evolution outlined in the preceding, but now occupies a "craton-margin" setting rather than the intracratonic situation of the Grand Banks basins to the west. Because this setting is analogous to that of the western margin of Galicia Bank (Fig. 1), aspects of crustal structure of the eastern Grand Banks margin and of structure and stratigraphy of the Carson Basin are reviewed in the following.

\section{The Continent/Ocean Boundary}

Delineation of the continent/ocean crustal boundary (COB) is of primary importance in assessing pre-drift positions of the continental plates, but the location of this boundary may vary according to the geophysical technique used to define it. The COB drawn in Figures 4 and 5 is the minimum seaward extent of continental crust in our interpretation of seismic-reflection data.

Notable zones of subsided continental crust occur adjacent to the Grand Banks crustal block, which has behaved as a relatively stable structural unit since the mid-Cretaceous. North of the Grand Banks, the East Newfoundland Basin (Fig. 3) is underlain by subsided continental crust (Keen and Barrett, 1981; Grant, 1987). South of the Grand Banks, the COB is drawn seaward of the Newfoundland Ridge (Figs. 4 and 5), where multichannel seismic data show gently dipping reflectors (Fig. 9) to depths approaching $4 \mathrm{~s}$ (two-way traveltime) below the seafloor. Grant (1979) compared the character of these reflectors to that observed in basinal areas on the Grand Banks and proposed that the Newfoundland Ridge is underlain by an analogous sedimentary basin. Absence of a significant gravity anomaly over this feature is further evidence that it is underlain by substantially lighter rocks than would compose a ridge of oceanic crust, as it was previously interpreted by Watson and Johnson (1970) and Sullivan and Keen (1978). Moreover, structures in the axial part of the basin (Fig. 5) appear to be piercements related to flowage of evaporites or shale (Fig. 9); rim synclines associated with these structures distinguish them from volcanic seamounts in the area (Grant and McAlpine, in press). Evaporites in this location conceivably could range in age from Carboniferous to Jurassic. The $10-\mathrm{km}$ contour in Figure 4 is a conservative out- 

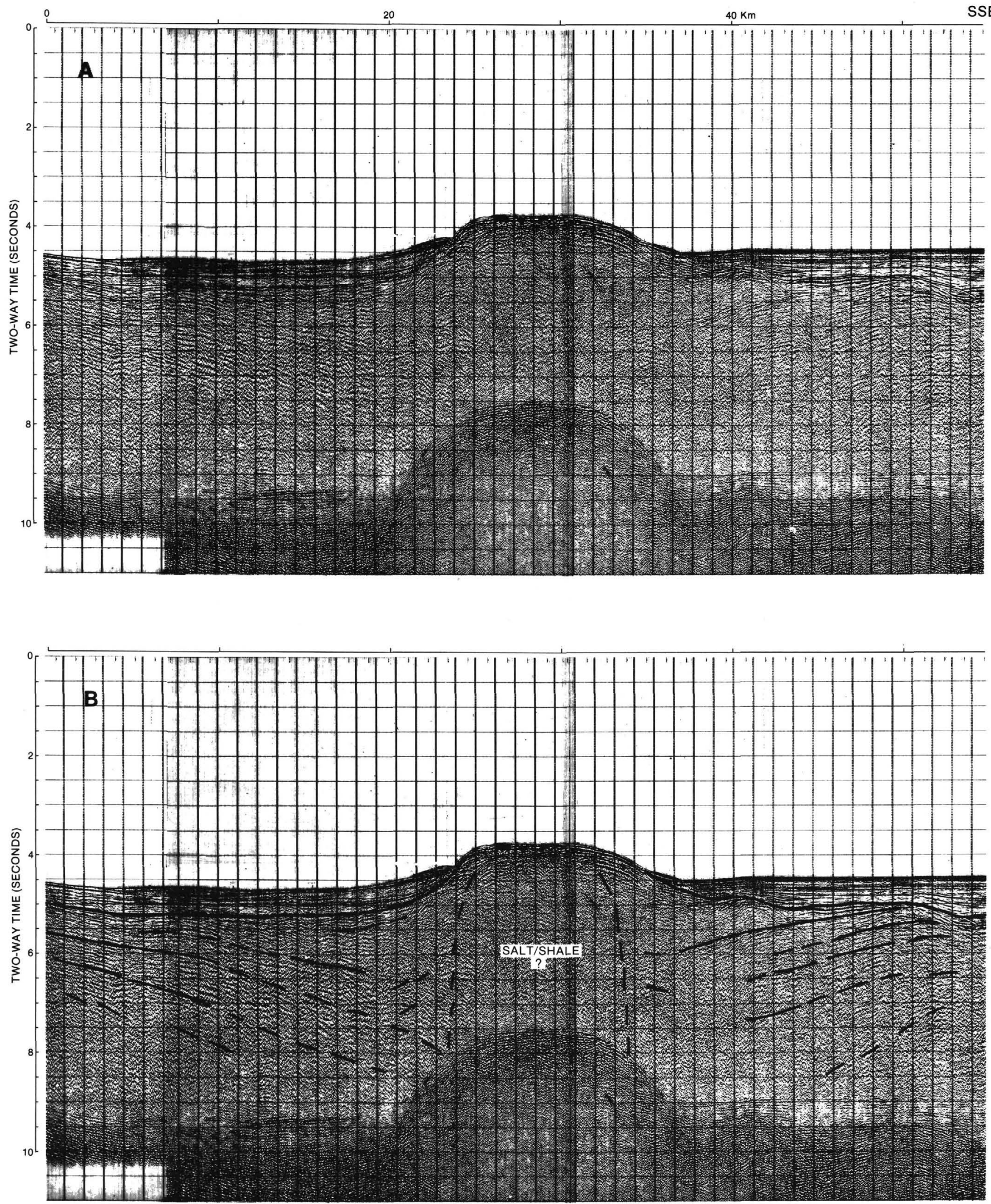

Figure 9. A. Seismic line (A) from Fogo Basin. Location of line shown in Figure 4. Part of line 121, 1972 (courtesy of Geophysical Service Incorporated). B. Interpretation of Figure 9A. 
line of the lateral extent and depth of this basin, which Grant and McAlpine (in press) have named the Fogo Basin. The area of the Fogo Basin underwent regional subsidence, but the strata that form the Newfoundland Ridge stand higher than their surroundings, possibly because of isostatic compensation. The Fogo Seamount cluster northwest of the Fogo Basin apparently lies on continental crust (Figs. 4 and 5), and scattered seamounts flank the basin to the northeast and southwest.

Newfoundland Ridge and Flemish Cap form promontories of continental crust projecting eastward from the Grand Banks continental block. Multichannel seismic data indicate that $\mathrm{Me}$ sozoic-Cenozoic sedimentary rocks in the Carson Basin extend seaward into the "embayment" between these promontories (Fig. $10)$. On the cross section in Figure 10, these rocks can be traced southeast for about $150 \mathrm{~km}$ to a northeast-trending ridge at a depth of about $6.0 \mathrm{~s}$. This ridge is the apparent seaward limit of the outer Carson Basin; it extends northeast to connect with the Beothuk Ridge (Figs. 4 and 5). In cross section D (Fig. 11), this ridge lies at a depth of $4.0 \mathrm{~s}$; the depth to the top of the Beothuk Ridge (cross section C; Fig. 11) is about $1.0 \mathrm{~s}$. The vertical dislocation of this ridge between sections $C$ and D (Fig. 11) is about $2.5 \mathrm{~km}$. Continental basement rocks lie seaward of this structure on Beothuk Ridge (C, Fig. 11), and similar rocks may be expected seaward of this ridge in deep water to the southwest (Fig. 10; D, Fig. 11). In fact, seismic data show a zone of relatively smooth basement seaward, with intrabasement reflectors. Parson et al. (1985) mapped "intermediate" basement in this zone, which they suggested might be transitional between continental and oceanic crust. They regarded the irregular basement surface to the east of this zone as displaying "normal" oceanic character. We suggest (Fig. 4) that continental crust extends at least to the seaward edge of Parson et al.'s (1985) “intermediate" zone.

Parson et al. (1985) also noted difficulties in using magnetic data in this area to locate the COB. The magnetic field is complex and the J anomaly (Fig. 2) could be projected across the Fogo Basin in different ways. Large and irregular anomalies associated with the Newfoundland Ridge highlight the anomalous structure of this zone. These anomalies tend to correlate with relief on the approximate mid-Cretaceous surface, with positive anomalies generally over structural highs and negative anomalies over lows. This correlation suggests that the magnetic anomalies may be associated with volcanic material deposited at the level of the unconformity, most obviously with the seamounts in this area. Analogous volcanic rocks have been drilled at the level of the unconformity in several wells on the Grand Banks (Jansa and Pe-Piper, 1986). Northeast of the Fogo Basin, proposed locations of the $\mathrm{COB}$ have been based on interpreted positions of the J anomaly (e.g., Tucholke and Ludwig, 1982; Sullivan, 1983; Masson and Miles, 1984). Tucholke and Ludwig (1982) and Sullivan (1983) placed the COB close to the line we have drawn in Figures 4 and 5 . Our boundary generally lies seaward of that proposed by Keen and de Voogd (in press), who have interpreted the structure that we relate to the outer margin of the Carson Basin as marking the COB. We note that the reconstruction of Srivastava and Tapscott (1986) based on interpretation of magnetic lineations results in overlap of Flemish Cap and Galicia Bank (Fig. 2).

\section{Carson Basin Structure}

The Carson Basin comprises several depocentres, the deepest containing over $10 \mathrm{~km}$ of Mesozoic-Cenozoic sediments (Fig. 4). The basin terminates to the southwest against the South Bank High and is separated from the south Jeanne d'Arc Basin to the west by a basement ridge (Figs. 4 and 5). This ridge probably is composed, in part, of Paleozoic granitic rocks such as encountered in the Jaeger A-49 well, radiometrically dated as
Devonian in age $(376 \pm 17 \mathrm{Ma}$; Amoco Canada, 1973). S. Hada (pers. comm., 1976) assigned these rocks to the adamellite category (vs. granodiorite) of Acadian intrusions in the Appalachians.

To the northeast, the Carson Basin extends into the area of the "Outer Ridge Complex," where basement rocks may be as old as Precambrian (Fig. 5). To the east, shallow drill cores from central Flemish Cap are composed of Hadrynian age granodiorite, minor granite, dacite, and some laminated, cherty volcanic sandstones metamorphosed to subgreenschist facies (Pelletier, 1971; King et al., 1985). Absolute age dating of the granodiorite provided $\mathrm{K}-\mathrm{Ar}$ ages on biotite and hornblende of $615 \pm 20 \mathrm{Ma}$. $\mathrm{U}-\mathrm{Pb}$ analysis of zircons from the granodiorite gave older ages of 751-833 Ma. King et al. (1985) related the younger biotite age from the granodiorite to superimposed subgreenschist metamorphism and concluded that these rocks are part of the Avalon Zone of the Appalachian Orogen.

The basement rocks exposed on central Flemish Cap are encircled by a veneer of outward-dipping sedimentary strata that are truncated at the flank of the cap. The depositional, erosional, and structural aspects of these sediments suggest that Flemish Cap has been a relatively positive crustal element through the Cenozoic and at least part of the Mesozoic. Because Flemish Cap is remote from sediment sources, the sediments on the cap probably reflect slow deposition in shallow water, with frequent lacunae. Sen Gupta and Grant (1971) reported Cretaceous foraminifers in a limestone specimen dredged from the southern flank of Flemish Cap.

On southwestern Flemish Cap, more than $3 \mathrm{~km}$ of sedimentary strata are present in a north-trending half-graben (Flemish Cap Basin) east of Beothuk Ridge (Figs. 4 and 5). These sediments are essentially undeformed but are underlain by deformed strata. If the latter are analogous to the deformed strata in Flemish Pass sampled by the Gabriel C-60 well, they may be Early Cretaceous in age and the undeformed sediments in the graben may thus be Late Cretaceous. Apart from some relatively local zones with a highly reflective basement surface, seismic data indicate that basement in this area is composed mainly of deformed sedimentary rocks. Grant (1972) compared the seismic character of rocks underlying Beothuk Ridge to that of Carboniferous strata on the shelf northeast of Newfoundland (Fig. 5).

The structure of the Carson Basin is illustrated by the cross section through the Bonnition $\mathrm{H}-32$ well in Figure 10. The prominent unconformity beneath the continental shelf is the surface mapped in Figure 3. This unconformity cuts Lower Cretaceous sedimentary rocks in the Bonnition well and Jurassic rocks beneath the outer shelf and continental slope. Some of the erosion at this level occurred in the Tertiary. The shelf edge presently lies roughly $30 \mathrm{~km}$ landward of a downwarp in the unconformity. This downwarp represents a major structural dislocation, defined here as separating the inner and outer Carson Basin. This is the same structural break that truncates the Beothuk Ridge (Fig. 11). The Cretaceous and Cenozoic section overlying the unconformity thickens abruptly seaward across this zone. Folding and faulting of the rocks beneath the unconformity reflect flowage of evaporites or shale and collapse of the margin on seaward-dipping faults. The ridge separating the inner and outer Carson Basin appears to be underlain by a basement block, and deep seismic events suggest that salt flowage may be associated with this structure.

Reflectors are evident beneath the unconformity to the foot of the scarp at a depth of $6 \mathrm{~s}(100 \mathrm{~km}$ in Fig. 10). Seaward from this point, the reflector defining the unconformity surface becomes irregular and difficult to trace on the single-channel profile used for this portion of the cross section. However, multichannel lines in this zone show deep reflectors, including struc- 

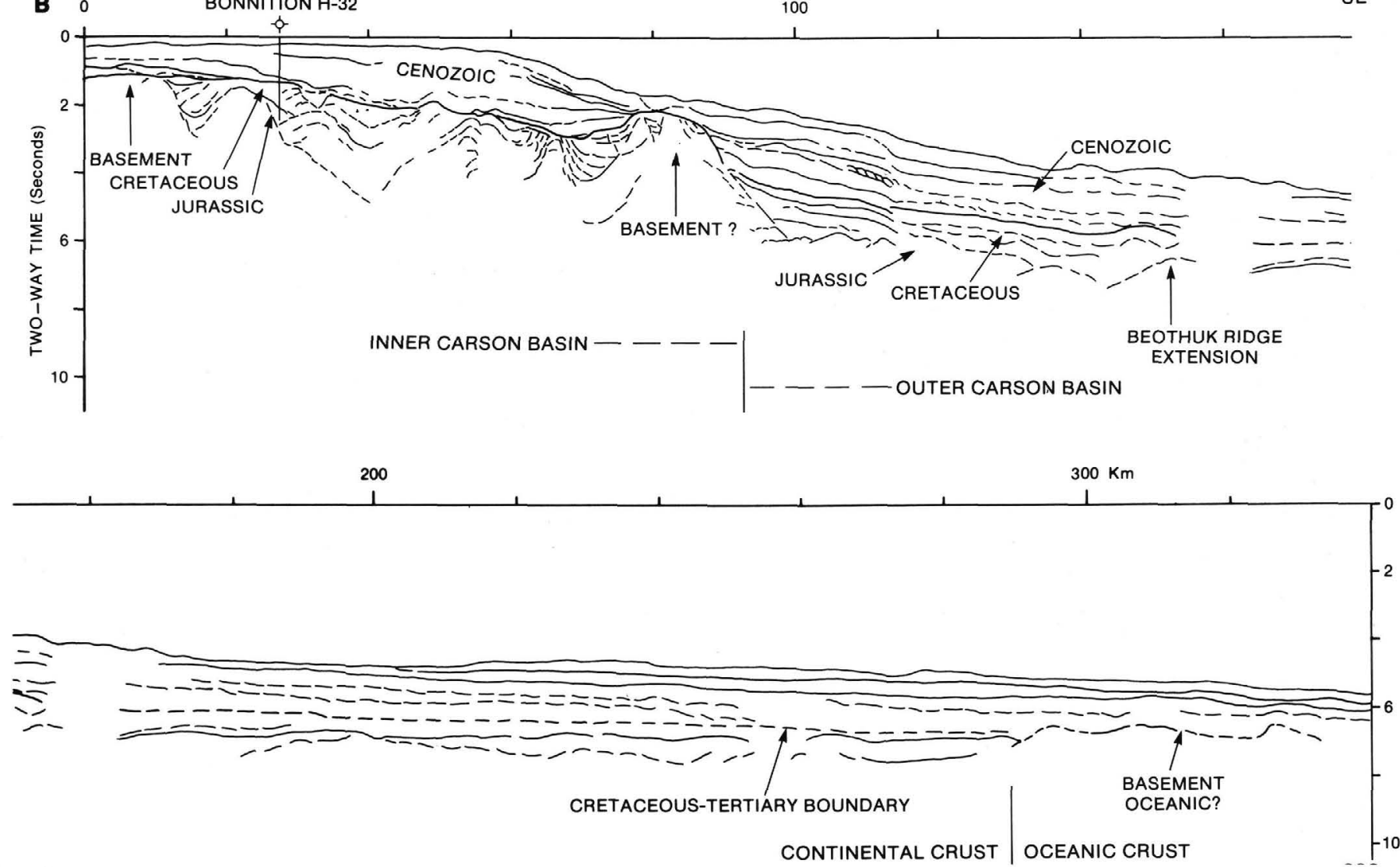

Figure 10. Seismic cross section (B) of the southeast margin of the Grand Banks. Location shown in Figure 4. Bold reflector is Avalon Unconformity to $90 \mathrm{~km}$; approximate base of Tertiary is from $90-340 \mathrm{~km}$. From the shelf seaward the cross section includes parts of line NF 79-103, 1980 (courtesy of Geophysical Service Incorporated); lines E-614, 1971, and G-564, 1973 (courtesy of Mobil Oil Corporation); line NF 79-107D, 1980 (courtesy of Geophysical Service Incorporated); and line S-215, 1977 (courtesy of Texaco Exploration Canada Limited). Southeast portion of section is courtesy of Institute of Oceanographic Sciences, U.K. (Parson et al., 1985).

tures interpreted as related to the flowage of evaporites or shale. These structures can be traced seaward to the outer limit of the Carson Basin at the Beothuk Ridge extension (150 km in Fig. 10).

\section{Carson Basin Stratigraphy}

Four exploratory wells (Fig. 4) have been drilled in the Carson Basin: Osprey G-84, Skua E-41, Bonnition H-32, and St. Georges J-55 (data from the St. Georges well are not yet released). The rocks in the released wells can be directly correlated with the depositional sequences defined for the Grand Banks in the Jeanne d'Arc Basin (Fig. 8). None of these wells reached pre-Mesozoic basement; the oldest rocks recovered are CarnianNorian coarse-grained continental clastics (Kettle Formation, sequence 1; Fig. 8) that underlie the Osprey evaporites in the Osprey well (Jansa et al., 1977). The evaporites, about $2 \mathrm{~km}$ thick, are dominated by halite with minor interbedded reddish argillaceous mudstones. The low bromine content of the halite, lack of any other evaporitic minerals, and intercalations of red beds may reflect extensive modification by freshwater inflow (Holser et al., in press). Alternatively, Jansa et al. (1980a) suggested lateral fractionation of brines to explain the monomineralic composition of evaporites in the Carson Basin. They speculated that the Carson Basin was contiguous with a larger evaporitic basin located between Grand Banks and Iberia. Seismic evidence (Fig. 10) for extension of the Carson Basin beneath the slope rise supports this speculation. Increasing marine influence is evidenced during the final stages of evaporite deposition by the occurrence of anhydrite and upward transition (Sinemurian-Pliensbachian) to shallow-marine carbonates (Iroquois Formation, sequence 2; Fig. 8).

The post-Pliensbachian Jurassic and Lower Cretaceous deposits, which are mainly shales, carbonates, and fine-grained clastics (Whale unit and Mic Mac and Missisauga Formations; Fig. 8), have been variably preserved in the Carson Basin as a result of their truncation at the Avalon Unconformity. The amount of erosional truncation in the basin increases southwestward toward the South Bank High (Fig. 5). In the Osprey well the unconformity truncates the top of the Iroquois carbonate. The sedimentary section is more fully preserved in the central and northern part of the basin, where Lower Cretaceous rocks underlie the unconformity in the Skua E-41 and Bonnition H-32 wells. The most complete Upper Jurassic-Lower Cretaceous sequence was encountered at Bonnition $\mathrm{H}-32$, and because it resembles the sequences encountered during Leg 103, its stratigraphy and depositional history are presented in Figure 12 for purposes of comparison with Galicia Bank. This sequence has been described in detail by Jansa et al. (1980b).

\section{EASTERN GRAND BANKS-GALICIA BANK COMPARISON}

Drilling data from ODP Leg 103 and extensive geophysical surveys of Galicia Bank (Mauffret and Montadert, 1987) now enable more detailed comparisons of the geologic evolution of the Iberian and Newfoundland margins than were possible pre- 

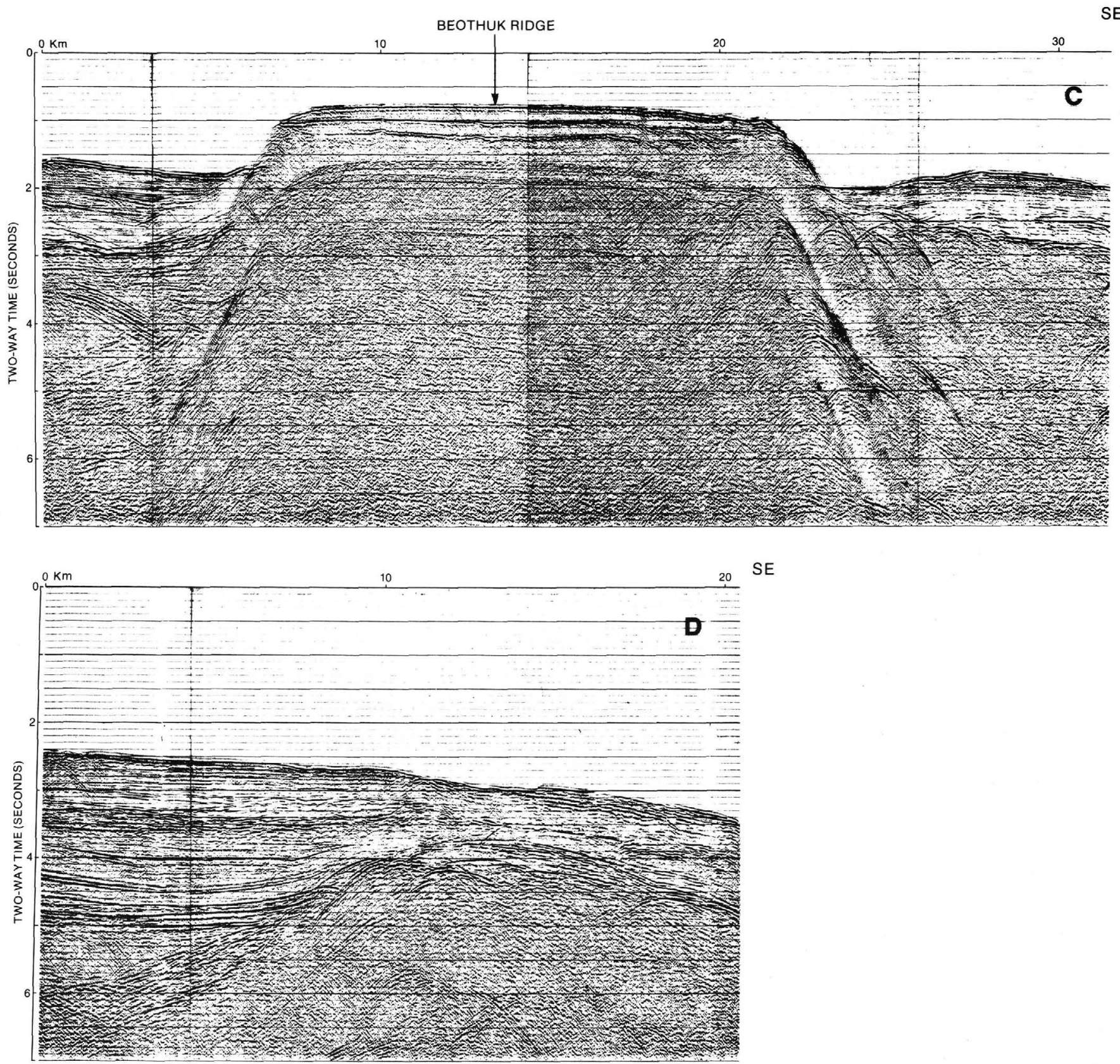

Figure 11. Seismic sections across Beothuk Ridge. Locations shown in Figure 4. C and D are parts of lines 80-1405 and 80-1407, 1981 (courtesy of Petro Canada).

viously. We briefly examine basement composition, tectonic framework, seismic sequences, lithofacies, and depositional environments of these two margins.

\section{Basement}

Basement beneath the eastern Grand Banks and Galicia Bank includes suites of similar sialic igneous rocks represented by granodiorites and minor granites, dacites, volcanoclastic sandstones, and low-grade metamorphics (King et al., 1985; Mougenot et al., 1985; Capdevila and Mougenot, this volume). The petrographic similarity of the igneous basement rocks indicates that these areas could have been part of the same geologic province, but the relative positions of Galicia Bank and Flemish Cap are not constrained by basement composition (Capdevila and
Mougenot, this volume). Absolute age dating of the rocks from Galicia Bank may assist in addressing this question.

\section{Tectonic Framework}

We have shown that the Mesozoic history of the eastern margin of the Grand Banks is a complex response to protracted rifting and continental breakup. The tectonic development of Galicia Bank is apparently less complex, but this may be due to the failure of Leg 103 to completely sample all pre-drift sequences (Mauffret and Montadert, 1987; Jansa et al., this volume). Leg 103 concentrated on the edge of the continental plate near the continent/ocean crustal boundary, where the tectonic style is dominated by slope failure with listric faults generating cascading sets of half-grabens. These tectonic conditions are similar to 


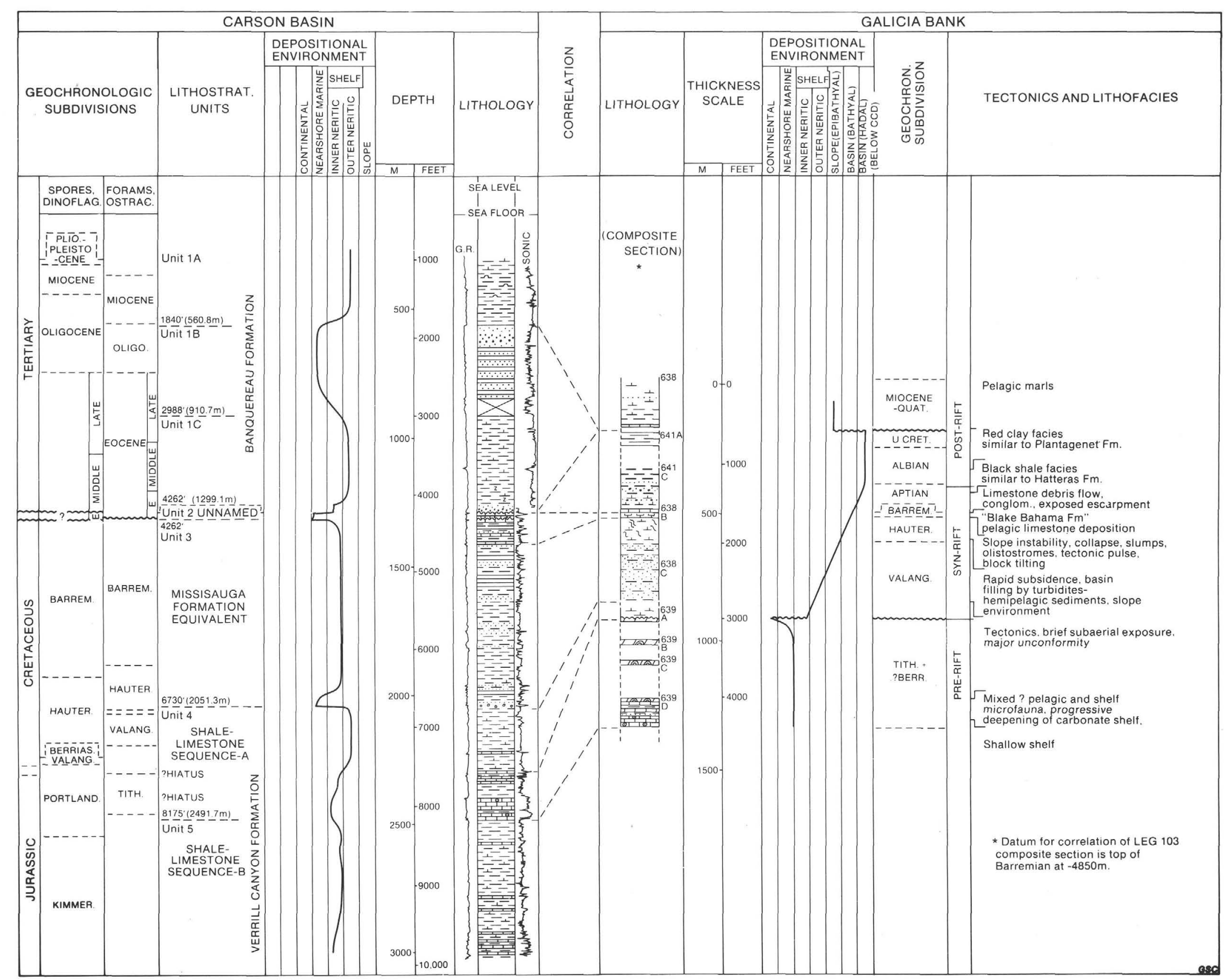


those in the outer Carson Basin beneath the continental slope and rise.

The presence of Carnian-Norian continental red beds and salt in the Carson Basin constrains the timing of the first Mesozoic tectonic period affecting the eastern Grand Banks to the Late Triassic. The onset of rifting on Galicia Bank has probably not been successfully defined by drilling. On the basis of seismic evidence, Jansa et al. (this volume), in contrast to Boillot et al. (1985), suggested that the Tithonian limestones encountered at Site 639 do not lie on basement but are underlain by at least 600 $\mathrm{m}$ of presumed Mesozoic sedimentary deposits. Similarly, Mauffret and Montadert (1987) indicate that locally up to $1200 \mathrm{~m}$ of sediments may underlie Upper Jurassic limestones. Because Triassic sandstones have been dredged on the Galicia Bank margin (Mougenot et al., 1985), the initiation of rifting on Galicia Bank could have been much earlier than suggested by Boillot et al. (1985).

Mauffret and Montadert (1987), on the basis of interpreted thick, pre-Upper Jurassic deposits and deep-faulted basement, suggested that rifting was initiated during the Oxfordian-Kimmeridgian. Mid-Kimmeridgian tectonism that resulted in formation of an angular unconformity on the Grand Banks, as discussed by Grant et al. (1986), Grant and McAlpine (in press), and Tankard and Welsink (in press), is only weakly represented by a facies change from a terrigenous sandstone-shale sequence to shale and limestone in the Carson Basin (Skua E-41). This event is difficult to associate with any regional tectonic event other than the onset of rifting between the Grand Banks and Iberia.

The Early Cretaceous on the Grand Banks was a tectonically active period, with block tilting and fault readjustment, propagation, and rejuvenation. The end of this period is associated with the mid-Cretaceous stage of development of the Avalon Unconformity on the Grand Banks. This stage is well developed in the Carson Basin, where, in places, later erosion produced post-Albian and Eocene unconformities. These three unconformities merge in the Bonnition H-32 well (Figs. 10 and 12). We associate the change of tectonic style at this unconformityfrom a tectonically active to a passive mode-with a decline in stress regimes as the continental crust between Flemish Cap and Galicia Bank separated and seafloor spreading began in this region in the late Aptian. A similar unconformity can be identified on seismic data from Galicia Bank (Boillot, Winterer, et al., 1987), although the existence of this unconformity has not been confirmed by drilling. Site 641 on Galicia Bank penetrated this seismic horizon and found the strata to be conformable with no lacuna (Boillot, Winterer, et al., 1987). The only change was lithologic, with an upward transition from conglomeratic and pebbly beds to shales across the seismic event. This stratigraphic level has been interpreted by Boillot, Winterer, et al. (1987) as representative of the post-rift unconformity on Galicia Bank, and it has been dated paleontologically as occurring at the Aptian/Albian boundary. Similarly, the outer Carson Basin stratal relations at the mid-Cretaceous unconformity are paraconformable in places. The mid-Cretaceous tectonic events represent the final regional Mesozoic period of structuring that is recognizable in the Carson Basin and is accompanied by significant salt tectonics and growth faulting. The last period of tectonism that we can recognize is probably of Eocene age, and it resulted in the development of an Eocene unconformity in the Carson Basin and the associated readjustment of some of the basement blocks.

\section{Seismic Sequences}

Multichannel seismic-reflection profiles from the outer Carson Basin beneath the continental slope and rise show seismostratigraphic units that correlate with those in the Jeanne d'Arc
Basin, the Galicia margin (Mauffret and Montadert, 1987), the Canadian continental margin (Parson et al., 1985), and the North American Basin (Jansa et al., 1979) (Fig. 13). The northern part of the outer Carson Basin is characterized by a series of southerly plunging ridges, grabens, and half-grabens. The grabens are filled by Jurassic-Cretaceous and Tertiary sedimentary rocks that can be traced northward into several grabens in the "Outer Ridge Complex" (Fig. 5). The separation of Mesozoic sediments into discrete basins and grabens is lost as the intervening ridges plunge southward and are buried by an increasing cover of Mesozoic strata. In this area, six major sequences are identified (Figs. 13 through 15).

The oldest seismic sequence, sequence 6 , is dominated by a series of high-amplitude events separated by thick intervals of low reflectivity in the inner Carson Basin. The top of this sequence is marked by a highly faulted surface characterized by a series of reflectors with high amplitude and low frequency. The beds are interpreted to include the Upper Jurassic carbonates recognized on the Galicia margin and penetrated at Bonnition $\mathrm{H}-32$ (Fig. 12). The unit is designated as formation $5 \mathrm{~b}$ by Mauffret and Montadert (1987) but is not recognized by Parson et al. (1985). We propose that the unit should be recognized separately as sequence 6 , thereby extending the nomenclature of Parson et al. (1985) and reflecting the change in depositional character above the carbonate and shale interval.

Seismic profiles show a considerable Mesozoic section below the total depth (3048 m) of the Bonnition H-32 well (Fig. 10). Within the inner Carson Basin, small stocklike diapirs of Lower Jurassic and Triassic salt are apparent with pre-salt reflectors below a depth of $7 \mathrm{~km}$. In the outer Carson Basin a strong reflection sequence correlates with the Tithonian-Kimmeridgian carbonates of the inner Carson Basin. However, thick sequences of pre-Kimmeridgian deposits are not observed, although some evidence of salt tectonics is seen. In updip areas the Upper Jurassic carbonates may rest directly on basement, an observation that is also made on the Iberian margin (Mauffret and Montadert, 1987).

Sequence 5 provides the major sedimentary fill in the basin and corresponds to formations 5a of Mauffret and Montadert (1987) and 5 of Parson et al. (1985). Sequence 5 is characterized by generally weak reflectivity, but a paraconformity in the axial part of the basin is marked by a single strong reflector. The upper part of sequence 5 is generally subparallel to the top of the strong seismic marker, and the sequence displays extreme growth across major faults. The character of the internal reflection is variable, ranging from strongly reflective parallel events on the crests of fault blocks to weakly reflective in the basin axes. This part of sequence 5 is probably of Hauterivian age.

The strong internal reflector of sequence 5 may represent the equivalent of the base of the sandy interval at $2051 \mathrm{~m}$ in the Bonnition $\mathrm{H}-32$ well, and the interval below this may be the equivalent of the Valanginian turbidites and pelagic marls encountered on Leg 103 in Hole 638C and at Site 639. Therefore, the lower section of sequence 5 would be a dominantly shaly interval of Valanginian-Berriasian age.

Sequence 4 , which is relatively thin, is marked at the base by a well-developed seismic marker, but this unit is seen clearly only in the basin axial zone. The unit is removed by erosion in structurally updip positions by the base of the sequence 3 unconformity. The base of the sequence 4 paraconformable event can be correlated to the base of sequence 4 ("transition to drift: phase 1"; Fig. 8) in this paper and to the $\beta$ horizon of Jansa et al. (1979). The internal character of sequence 4 is generally dominated by weak reflectivity, with some tendency for weakly mounded reflectivity to develop in the basin center. It is interpreted that the interval is composed of alternating marls, pelagic carbonates, and turbidites; the sequence is of BarremianAptian age. 


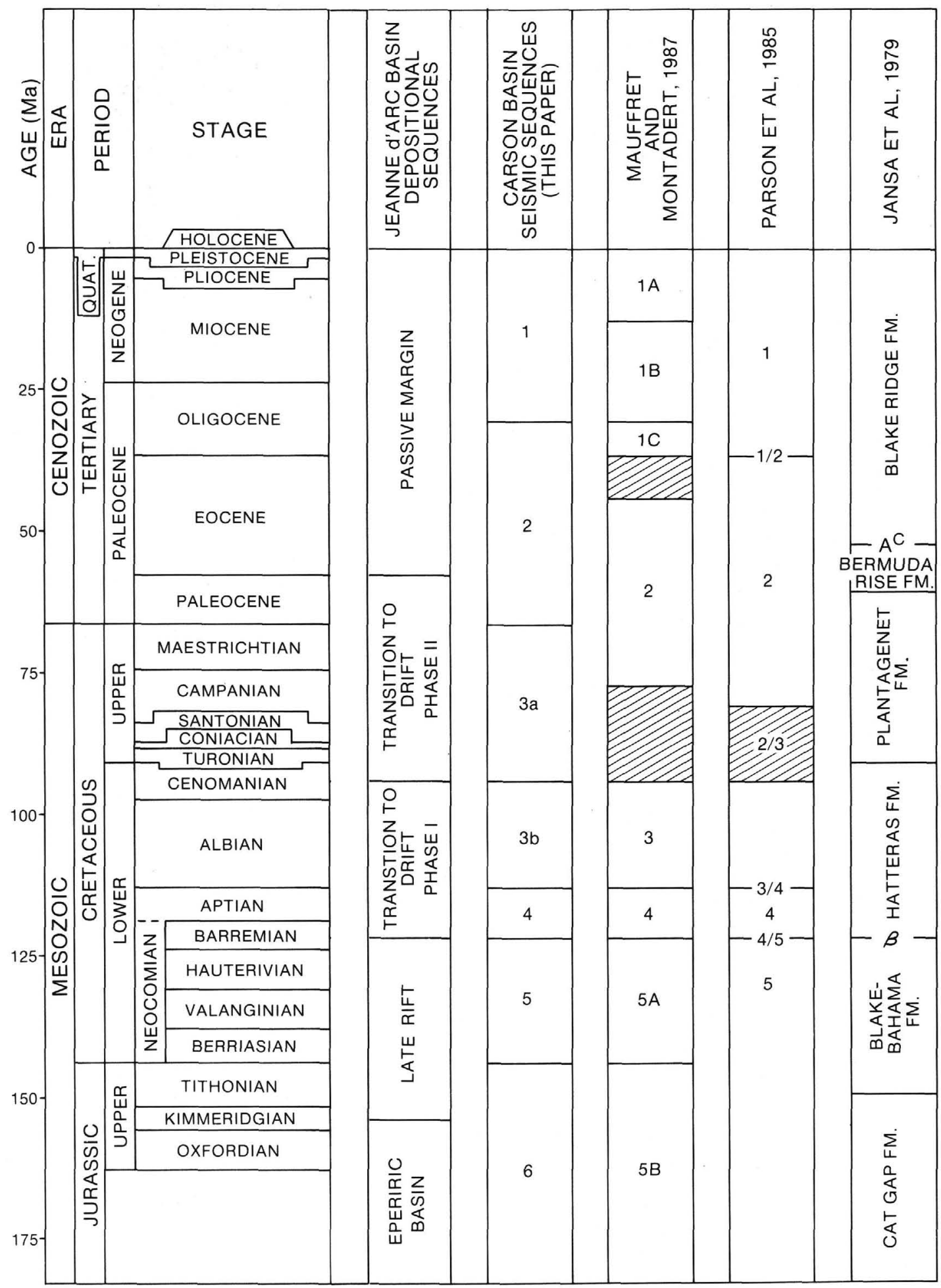

Figure 13. Seismic stratigraphies proposed for the North Atlantic, compared to those proposed in this paper.

The top of sequence 3 is the base of the Tertiary unconformity on the basin margins and ridges, which becomes paraconformable in the axial zone of the basin. At Bonnition $\mathrm{H}-32$ a lower Eocene section overlies a thin $(8.5-\mathrm{m})$ interval of sediments of possible mid-Cretaceous age that in turn unconformably overlies Barremian strata. Subcrop to the base of the Tertiary unconformity is seen to range from probable Paleozoic to Upper Cre- taceous, with the most significant erosion evidenced on ridge flanks and the updip sides of half-grabens (Fig. 15).

The base of Sequence 3 is marked by a third regional unconformity that can be recognized in the Grand Banks basins. In the Jeanne d'Arc Basin a major erosional unconformity of probable Aptian age can be identified; subcrop and erosion of quences younger than Barremian are seen (Fig. 7). On the basis 


(10
A

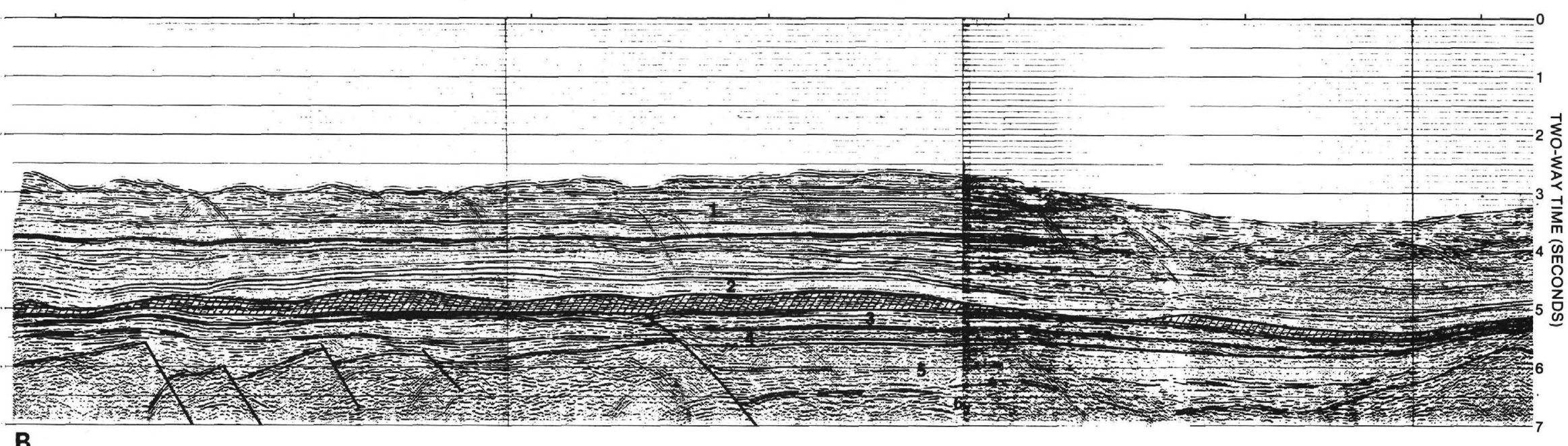

Figure 14. A. Seismic section (E) from the southeast margin of the Grand Banks. Location shown in Figure 4. Part of line 80-1404, 1981 (courtesy of Petro Canada). B. Interpretation of Figure 14A. Numbers indicate seismic units. Crosshatched interval denotes turbidites. 


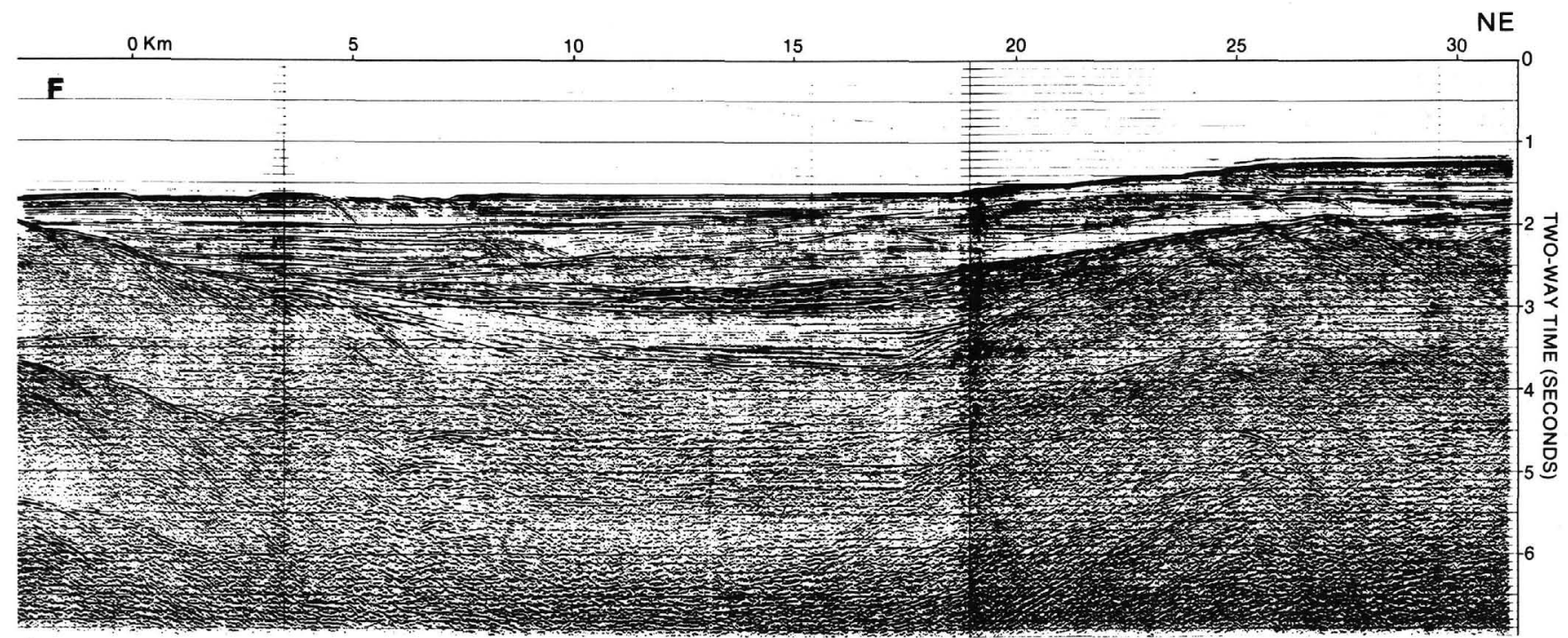

A

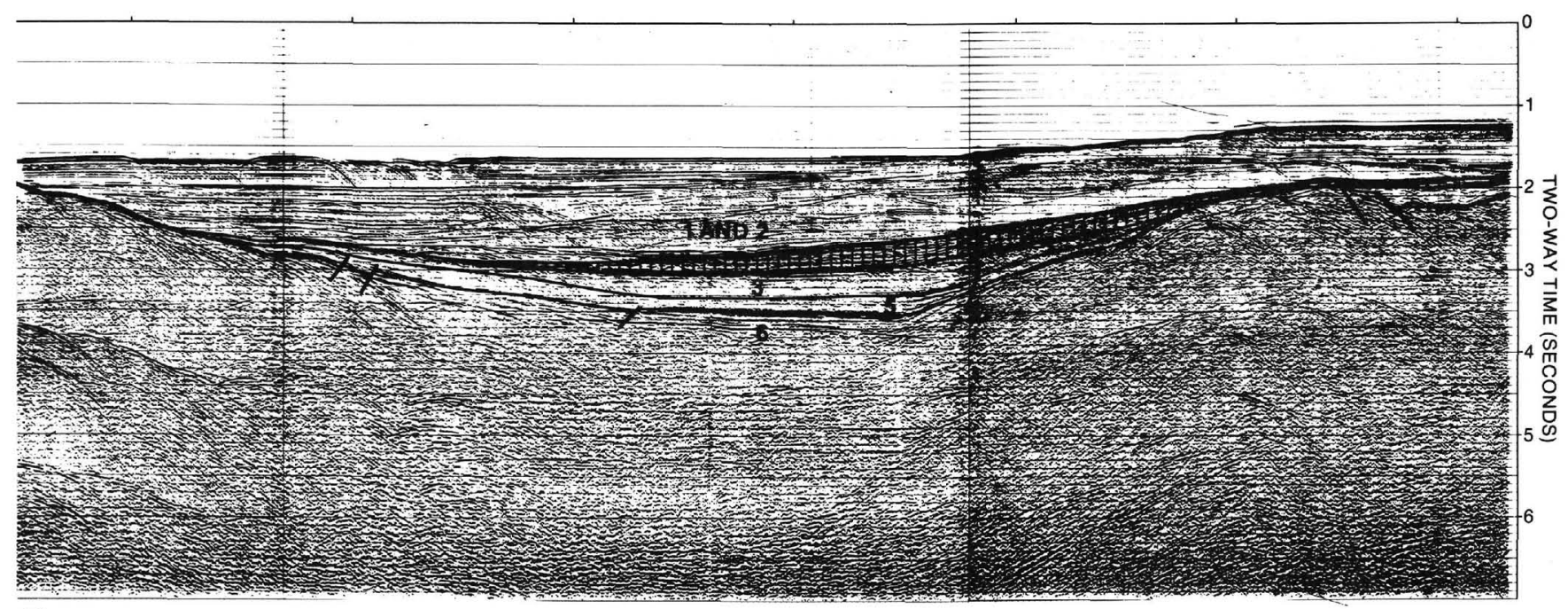

B

Figure 15. A. Seismic section (F) from the southeast margin of the Grand Banks. Location shown in Figure 4. Part of line 81-1404, 1981 (courtesy of Petro Canada). B. Interpretation of Figure 15A. Numbers indicate seismic units. Crosshatched interval denotes turbidites.

of its character and form, the base of sequence 3 is interpreted as the same erosional event evidenced in the Carson and Jeanne d'Arc basins. Sequence 3 is dominantly a seismically transparent zone and would appear to correlate in part with the lower section of formations 2 and 3 of Mauffret and Montadert (1987) and Parson et al. (1985).

In the deep basin areas, seismic evidence suggests that sequence 3 may be subdivided into upper (3a) and lower (3b) intervals (Fig. 14). The $3 a$ section may represent a condensed, although complete, Upper Cretaceous sedimentary sequence preserved beneath the Paleocene turbidites. On the basin margins and in updip structural positions this sequence is absent as a result of either nondeposition during the early Tertiary lowstand or erosion by the early Tertiary unconformity. Sequence 3a, which is only weakly reflective and very thin, may correlate with the red clay facies of the Plantagenet Formation (Jansa et al., 1979), the occurrence of which at Galicia Bank has been confirmed by ODP Leg 103 . Sequence $3 \mathrm{~b}$ is interpreted to represent the Albian to Cenomanian black shale, equivalent to the Hatteras Formation of the North Atlantic. This facies is well devel- oped at Hole $641 \mathrm{C}$ on the Galicia Bank margin (Fig. 16). Both Mauffret and Montadert (1987) and Parson et al. (1985) place the base of the sequence at the top of the Aptian.

Sequence 2 is marked at its base by a major unconformity, the base of the Tertiary unconformity. The interval is composed of a thick sequence of lower Oligocene, Eocene, and interpreted Paleocene sediments. The lower Oligocene is probably represented by a thin sequence of high-amplitude reflectors beneath the mid-Oligocene unconformity. The majority of sedimentary fill in this interval is composed of a series of progradational units of Eocene age; reflectivity is associated with the top of each depositional unit and there is a lack of reflector contrast within the unit.

In the axial areas of the basin the base of the Tertiary unconformity is overlain by an extensive, turbiditic sequence (Fig. 4). This unit is interpreted to be of Paleocene age and appears to be the continuation of a series of Maestrichtian-Paleocene turbidites recognized from the southern margin of Nova Scotia to the outer Carson Basin and in the Jeanne d'Arc Basin ("Paleocene sands"; Fig. 8). We interpret such fans to be the product of 


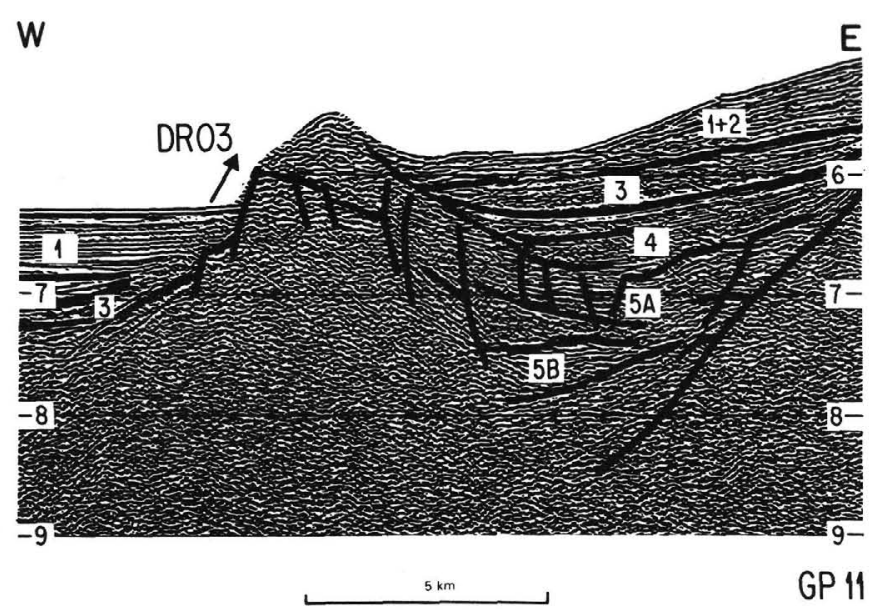

Figure 16. Seismic section from the continental margin off Galicia Bank. After Mauffret and Montadert (1987; fig. 13).

shelf-edge erosion during the post-Cretaceous lowstand (Vail et al., 1977). To the south of Bonnition H-32, a major channel that makes a deep cut into the Lower Cretaceous is interpreted to be a submarine canyon that channeled sediment onto an early Tertiary submarine slope (Fig. 15). Similar channels are observed in the Jeanne d'Arc Basin. In half-graben settings the inferred Paleocene sequence is interpreted as clastic fans developed from basin margin fault scarps (Fig. 15).

Sequence 1 extends from the sea bottom to a major regional unconformity of mid-Oligocene age recognized by Vail et al. (1977) as a major sea-level lowstand. The shallowest unit recognized by Mauffret and Montadert (1987), formation 1, was subdivided by those authors into three subunits, the lowest of which (1c) they assigned to the lower Oligocene encountered at DSDP Site 398. Therefore, in the divisions proposed here, the base of sequence 1 would correlate to the top of formation $1 \mathrm{c}$ on the Galicia Bank.

\section{Sedimentary Facies and Environment}

The oldest dated sediments from the Galicia margin are Tithonian limestones, which were interpreted by Jansa et al. (this volume) to be shallow shelf deposits. It is not clear whether the carbonates formed isolated banks or rimmed platforms surrounding tilted edges of tectonic blocks or if they were deposited on a low-angle ramp. The mixing of shallow-water biota (such as the large foraminifer Anchispirocyclina lusitanica, dasycladacean algae, and hydrozoans) and pelagic microfauna (calpionellids) suggests that deposition occurred near the shelf edge and that a deeper Late Jurassic basin existed seaward of ODP Site 639. Tithonian limestones of similar composition intercalated with neritic shales occur in the Bonnition and Skua wells in the Carson Basin (Jansa et al., 1980b). Mechanical logs for Site 639 indicate that the Upper Jurassic limestones also are intercalated with clastics (Jansa et al., this volume). The paleogeographic interpretation of the Carson Basin and the drilling results from the flank of Vigo Seamount (Jansa, 1978; Sibuet, Ryan, et al., 1979) are consistent with the existence of a deeper Jurassic basin south of Galicia Bank. Galicia Bank, Flemish Cap, and the Carson Basin were elements of the shelf that rimmed this basin.

The Tithonian and Berriasian boundary in the Carson Basin may be a short diastem, which was followed by deposition of deep neritic shales that continued into the Hauterivian. This diastem may be correlative with a period of major block tilting on Galicia Bank, in which the Jurassic limestones were uplifted and dolomitized. The tectonic block investigated by ODP Leg
103 subsided rapidly during the Valanginian as hemipelagic slope deposits followed by sand turbidites were deposited on top of the unconformity.

The combination of rapid deposition and fast subsidence during the Early Cretaceous resulted in slope instability and formation of the megaslumps and olistostromes shown by seismic profiles on Galicia margin (Mauffret and Montadert, 1987). We suggest that the Hauterivian sequence in Hole 638B is of such an origin. The slump is covered by Barremian pelagic carbonates similar to Blake-Bahama Formation lithologies known from the central North Atlantic Basin (Jansa et al., 1979). This indicates that the ocean floor forming between Galicia Bank and Flemish Cap at this time had already subsided to the same level as the floor of the North Atlantic Ocean Basin. The water depth during Barremian was between 2500 and $3000 \mathrm{~m}$. This subsidence might be interpreted as exceptional and rapid, but this is not the case. Considering the uncertainty in the initiation of foundering of the tectonic block where Site 639 is located, the average subsidence rate for the Berriasian-Barremian period was either 12.5 or $19 \mathrm{~cm} / 1000 \mathrm{yr}$, depending upon which boundary (Berriasian/Tithonian or Berriasian/Valanginian) is used for calculation. The first value is of the same magnitude as the regional subsidence of the sedimentary basins on the Grand Banks (Gradstein et al., 1977). In the Carson Basin during the late Hauterivian and Barremian, neritic sandstone and shale were deposited, with the top of the sequence cut by the Avalon Unconformity. The facies and environmental differences of the uppermost Lower Cretaceous deposits stem not so much from different tectonic settings as from contrasting conditions of sediment supply. The deposits investigated by Leg 103 were on a starved outer continental margin with individual tectonic blocks involved in overall margin subsidence. In contrast, the tectonically similar inner Carson Basin has been continuously infilled by sediments, with sediment supply keeping pace with subsidence.

The post-rift unconformity in the Bonnition well cannot be better constrained paleontologically than post-Barremian to pre?Albian-Eocene, as two or three. unconformities may be present within an $8 \mathrm{~m}$ interval (Fig. 12). No unconformity has been detected at ODP Site 641 , but the sharp change upward in the character of deposition, as indicated by the disappearance of conglomeratic and pebbly beds in the core, is here interpreted to correspond to the same interval and has been dated micropaleontologically as late Aptian (Boillot, Winterer, et al., 1987). Dark gray shales of Albian age, lithologically similar to the black shales of the Hatteras Formation of the North Atlantic, are well developed on the Iberian margin and indicate deposition below the carbonate compensation depth. They do not have a known counterpart in the shallow inner Carson Basin, but a seismically similar facies (sequence $3 \mathrm{~b}$ ) can be interpreted as occurring locally in the outer Carson Basin in the lower continental rise area.

In parts of the Carson Basin, the upper Cretaceous is missing or represented by Campanian-Santonian chalks, as in the Skua well (Barss et al., 1979) where they are truncated by an Eocene unconformity. Red clays encountered on Galicia Bank at Sites 640 and 641 represent a period of nondeposition or very slow deposition in the evolving oceanic basin. The red color is the result of high oxidation during low deposition and does not necessitate oceanographic change. These clays are lithologically and stratigraphically similar to the Plantagenet Formation of the central Atlantic (Jansa et al., 1979) and attest to the expansion of the central North Atlantic depositional and paleoceanographic regime into the Galicia-Flemish Cap area during the Late Cretaceous.

The Tertiary sequences on the eastern Grand Banks margin are lithologically variable, with chalks, marls, siliceous mud- 
stones, and coarse clastics deposited in response to mainly eustatic and climatic changes. Corresponding stratigraphic data are not available from Leg 103 , because in order to achieve maximum penetration of Mesozoic strata, the Tertiary section was bypassed by drilling in a Miocene channel.

\section{CONCLUSIONS}

Six main depositional sequences based on regional seismostratigraphic units confirmed by well data can be defined for the Mesozoic-Cenozoic basins on the Grand Banks in terms of the main events in the tectonic evolution of the North Atlantic. The stratigraphy of the inner Carson Basin on the southwest flank of the Grand Banks is typical of these basins. Based on analysis of multichannel seismic data, this stratigraphy can be extrapolated to the outer Carson Basin beneath the present slope-rise zone southeast of the Grand Banks. The seismic stratigraphy of this zone can be compared on a unit by unit basis with that of the Galicia margin, indicating that these two regions had similar tectonic histories and depositional environments from the Triassic to Tertiary. In addition, similarities of Mesozoic and older basement rocks on the Grand Banks and Galicia margins suggest that these regions may have been part of the same geologic province prior to formation of the North Atlantic. Evidence for foundered continental crust in the slope-rise zone southeast of the Grand Banks appears to preclude pre-drift reconstructions that place Galicia Bank within this zone.

\section{ACKNOWLEDGMENTS}

We thank G. Boillot, F. M. Gradstein, and J. A. Wade for helpful comments on this paper, N. Koziel for typing, and G. Cook for drafting the illustrations.

Geological Survey of Canada Contribution no. 41887.

\section{REFERENCES}

Amoco Canada Petroleum Company Ltd. and Imperial Oil Ltd., 1973. Regional geology of the Grand Banks. Bull. Can. Pet. Geol., 21: 479-503.

Amoco Canada Petroleum Company Ltd., 1973. Well history report, Amoco-Imperial A-1 Jaeger A-49.

Barss, M. S., Bujak, J. P., and Williams, G. L., 1979. Palynological zonation and correlation of sixty-seven wells, eastern Canada. Pap. Geol. Surv. Can., 78-24.

Boillot, G., Winterer, E. L., Meyer, A. W., Applegate, J., Baltuck, M., Bergen, J. A., Comas, M. C., Davies, T. A., Dunham, K., Evans, C. A., Girardeau, J., Goldberg, D., Haggerty, J., Jansa, L. F., Johnson, J. A., Kasahara, J., Loreau, J.-P., Luna-Sierra, E., Moullade, M., Ogg, J., Sarti, M., Thurow, J., and Williamson, M. W., 1985. Résultats préliminaires de la campagne $103 \mathrm{du}$ JOIDES Resolution (ODP) au large de la Galice (Espagne): sédimentation et distension pendant le "rifting" d'une marge stable; hypothèse d'une dénudation tectonique du manteau supérieur. C. R. Acad. Sci. Ser. 2, 301: 627-632.

Boillot, G., Winterer, E. L., et al., 1987. Proc. ODP, Init. Repts., 103: College Station, TX (Ocean Drilling Program).

de Graciansky, P. C., Poag, C. W., et al., 1985. Init. Repts. DSDP, 80: Washington (U.S. Govt. Printing Office).

Enachescu, M. E., 1987. Tectonic and structural framework of the northeast Newfoundland continental margin. In Beaumont, C., and Tankard, A. J. (Eds.), Sedimentary Basins and Basin-Forming Mechanisms: Mem. Can. Soc. Pet. Geol., 12:117-146.

Gradstein, F. M., Grant, A. C., and Jansa, L. F., 1977. Grand Banks and J-Anomaly Ridge: a geological comparison. Science, 197:10741076.

Gradstein, F. M., and Williams, G. L., 1981. Stratigraphic charts of the Labrador and Newfoundland shelves. Open File Rep. (Geol. Surv. Can.), 826.

Grant, A. C., 1972. The continental margin off Labrador and eastern Newfoundland; morphology and geology. Can. J. Earth Sci., 9: 1394-1430.
1975. Structural modes of the western margin of the Labrador Sea. In van der Linden, W.J.M., and Wade, J. A. (Eds.), Offshore Geology of Eastern Canada: Pap. Geol. Surv. Can., 74-30: 217-231.

1979. Geophysical observations bearing upon the origin of the Newfoundland Ridge. Tectonophysics, 59:71-82.

1987. Inversion tectonics on the continental margin east of Newfoundland. Geology, 15:845-848.

Grant, A. C., and McAlpine, K. D., in press. The continental margin around Newfoundland. In Keen, M. J., and Williams, G. L. (Eds.), Geology of the Continental Margin off Eastern Canada: Geol. Surv. Can. Geol. Can., 2.

Grant, A. C., McAlpine, K. D., and Wade, J. A., 1986. The continental margin of Eastern Canada-geological framework and petroleum potential. In Halbouty, M. T. (Ed.), Future Petroleum Provinces of the World: Mem. Am. Assoc. Pet. Geol., 40:177-205.

Hodych, J. P., and Hayatsu, A., 1980. K-Ar isochron age and paleomagnetism of diabase along the trans-Avalon aeromagnetic lineament; evidence of Late Triassic rifting in Newfoundland. Can. J. Earth Sci., 17:491-499.

Holser, W. T., Clement, G. P., Jansa, L. F., and Wade, J. A., in press. Evaporite deposits of the North Atlantic rift. In Manspeizer, W. (Ed.), Triassic-Jurassic Rifting and the Opening of the Atlantic: Amsterdam (Elsevier).

Hubbard, R. J., Pape, J., and Roberts, D. G., 1985. Depositional sequence mapping to illustrate the evolution of a passive continental margin. In Berg, O. R., and Woolverton, D. C. (Eds.), Seismic Stratigraphy II: Mem. Am. Assoc. Pet. Geol., 39:93-115.

Jansa, L. F., 1978. Le Crétacé au large de la marge Ibérique. Cah. Micropaleontol., 4:47-56.

Jansa, L. F., Bujak, J. P., and Williams, G. L., 1980a. Upper Triassic salt deposits of the western North Atlantic. Can. J. Earth Sci., 17: 547-559.

Jansa, L. F., Enos, P., Tucholke, B. E., Gradstein, F. M., and Sheridan, R. E., 1979. Mesozoic-Cenozoic sedimentary formations of the North American Basin, western North Atlantic. In Talwani, M., Hay, W., and Ryan, W.B.F. (Eds.), Deep Drilling Results in the Atlantic Ocean: Continental Margins and Paleoenvironments: Am. Geophys. Union, Maurice Ewing Ser., 3:1-57.

Jansa, L. F., Gradstein, F. M., Williams, G. L., and Jenkins, W.A.M., 1977. Geology of the Amoco Imp. Skelly A-1 Osprey H-84 well, Grand Banks, Newfoundland. Pap. Geol. Surv. Can., 77-21:17.

Jansa, L. F., and Pe-Piper, G., 1986. Geology and geochemistry of Middle Jurassic and Early Cretaceous igneous rocks on the eastern North American continental shelf: 1. Open File Rep. Geol. Surv. Can., 1351.

Jansa, L. F., Remane, J., and Ascoli, P., 1980b. Calpionellid and foraminiferal-ostracod biostratigraphy of the Jurassic-Cretaceous boundary, offshore eastern Canada. Riv. Ital. Paleontol., 86:67-126.

Jansa, L. F., and Wade, J. A., 1975. Geology of the continental margin off Nova Scotia and Newfoundland. In van der Linden, W.J.M., and Wade, J. A. (Eds.), Offshore Geology of Eastern Canada: Pap. Geol. Surv. Can., 74-30:51-106.

Jansa, L. F., and Wiedmann, J., 1982. Mesozoic-Cenozoic development of the eastern North American and northwest African continental margins: a comparison. In von Rad, U., Hinz, K., Sarnthein, M., and Seibold, E. (Eds.), Geology of the Northwest African Continental Margin: Berlin (Springer-Verlag), 215-269.

Keen, C. E., and Barrett, D. L., 1981. Thinned and subsided continental crust on the rifted margin of eastern Canada, thermal evolution and subsidence history. Geophys. J. R. Astron. Soc., 65:443-465.

Keen, C. E., Boutilier, R., de Voogd, B., Mudford, B., and Enachescu, M., in press. Crustal geometry and models of the evolution of the rift basins on the Grand Banks of Eastern Canada; constraints from deep seismic data. In Beaumont, C., and Tankard, A. J. (Eds.), Sedimentary Basins and Basin-Forming Mechanisms: Mem. Can. Soc. Pet. Geol., 12:101-115.

Keen, C. E., and de Voogd, B., in press. The continental-ocean boundary at the rifted margin off eastern Canada: new results from deep seismic reflection profiling. Tectonics.

King, L. H., Fader, G. B., Poole, W. H., and Wanless, R. K., 1985. Geological setting and age of the Flemish Cap granodiorite. Can. J. Earth Sci., 22:1286-1298. 
Masson, D. G., and Miles, P. R., 1984. Mesozoic seafloor spreading between Iberia, Europe and North America. Mar. Geol., 56:279-287. 1986. Development and hydrocarbon potential of Mesozoic sedimentary basins around margins of North Atlantic. AAPG Bull., 70:721-729.

Mauffret, A., and Montadert, L., 1987. Rift tectonics on the passive continental margin of Galicia (Spain). Mar. Pẹt. Geol., 4:49-70.

McAlpine, K. D., Bell, J. S., Avery, M. P., Snowdon, L. R., and Brooks, P. W., 1986. Hydrocarbon generation in the Jeanne d'Arc Basin, offshore Newfoundland [paper presented at Geol. Surv. Can. forum: Activities on Oil and Gas in Canada, Calgary].

McWhae, J.R.H., 1981. Structure and spreading history of the northwestern Atlantic region from the Scotian Shelf to Baffin Bay. In Kerr, J. W., and Ferguson, A. J. (Eds.), Geology of the North Atlantic Borderlands: Mem. Can. Soc. Pet. Geol., 7:299-332.

Mougenot, D., Capdevila, R., Palain, C., Dupeuble, P. A., and Mauffret, A., 1985. Nouvelles données sur les sédiments anterift et le socle de la marge continentale de Galice. C. R. Acad. Sci. Ser. 2, 301: 323-328.

Parson, L. M., Masson, D. G., Pelton, C. D., and Grant, A. C., 1985. Seismic stratigraphy and structure of the east Canadian continental margin between $41^{\circ} \mathrm{N}$ and 52 $\mathrm{N}$. Can. J. Earth Sci., 22:686-703.

Pelletier, B. R., 1971. A granodioritic drill core from the Flemish Cap, eastern Canadian continental margin. Can. J. Earth Sci., 8:14991503.

Powell, T. G., 1984. Hydrocarbon-source relationships, Jeanne d'Arc and Avalon basins, offshore Newfoundland. Open File Rep. Geol. Surv. Can., 1094.

Sen Gupta, B. K., and Grant, A. C., 1971. Orbitolina, a Cretaceous larger foraminifera, from Flemish Cap: paleoceanographic implications. Science, 173:934-936.

Sibuet, J.-C., Ryan, W.B.F., et al., 1979. Evolution of the west Iberia passive margin in the framework of the early evolution of the North Atlantic Ocean. In Sibuet, J.-C., Ryan, W.B.F., et al., Init. Repts. DSDP, 47, Pt. 2: Washington (U.S. Govt. Printing Office), 761-775.

Srivastava, S. P., and Tapscott, C. R., 1986. Plate kinematics of the North Atlantic. In Vogt, P. R., and Tucholke, B. E. (Eds.), The Ge- ology of North America: The Western North Atlantic Region: Geol. Soc. Am. DNAG Ser., M:379-404.

Stam, B., 1986. Quantitative analysis of Middle and Late Jurassic foraminifera from Portugal and its implication for the Grand Banks of Newfoundland. Utrecht Micropaleontol. Bull., 34.

Sullivan, K. D., 1983. The Newfoundland Basin: ocean-continent boundary and Mesozoic seafloor spreading history. Earth Planet. Sci. Lett., 62:321-339.

Sullivan, K. D., and Keen, C. E., 1978. On the nature of the crust in the vicinity of the southeast Newfoundland Ridge. Can. J. Earth Sci., 15:1462-1471.

Swift, J. H., and Williams, J. A., 1980. Petroleum source rocks, Grand Banks area. In Miall, A. D. (Ed.), Facts and Principles of World Petroleum Occurrence: Mem. Can. Soc. Pet. Geol., 6:567-588.

Tankard, A. J., and Welsink, H. J., in press. Extensional tectonics and stratigraphy of the Mesozoic Grand Banks of Newfoundland. In Manspeizer, W. (Ed.), Triassic-Jurassic Rifting and the Opening of the Atlantic: Amsterdam (Elsevier).

Tucholke, B. E., and Ludwig, W. J., 1982. Structure and origin of the JAnomaly Ridge, western North Atlantic Ocean. J. Geophys. Res., 87:9389-9407.

Vail, P. R., Mitchum, R. M., Jr., Todd, R. G., Widmier, J. M., Thompson, S., III, Sangree, J. B., Bubb, J. N., and Hatelid, W. G., 1977. Seismic stratigraphy and global changes of sea level. In Payton, C. E. (Ed.), Seismic Stratigraphy: Applications to Hydrocarbon Exploration: Mem. Am. Assoc. Pet. Geol., 26:49-212.

Watson, J. A., and Johnson, G. L., 1970. Seismic studies in the region adjacent to the Grand Banks of Newfoundland. Can. J. Earth Sci., 7:306-316.

Wernicke, B., 1985. Uniform-sense normal simple shear of the continental lithosphere. Can. J. Earth Sci., 22:108-125.

Williams, H., 1979. Appalachian Orogen in Canada. Can. J. Earth Sci., 16:792-807.

Date of initial receipt: 1 June 1987

Date of acceptance: 10 February 1988

Ms 103B-173 